\title{
Oxido-reduction sequence related to flux variations of groundwater from a fractured basement aquifer (Ploemeur area, France)
}

\author{
C. Tarits ${ }^{\mathrm{a}, *}$, L. Aquilina ${ }^{\mathrm{b}}$, V. Ayraud ${ }^{\mathrm{b}, \mathrm{c}}$, H. Pauwels ${ }^{\mathrm{c}}$, P. Davy ${ }^{\mathrm{b}}$, \\ F. Touchard ${ }^{\mathrm{b}}$, O. Bour ${ }^{\mathrm{b}}$ \\ ${ }^{a}$ IUEM, UMR CNRS 6538, Université de Bretagne Occidentale, 6 Avenue Le Gorgeu, C.S. 93837, F-29238 Brest Cedex 3, France \\ b CAREN - Géosciences Rennes, UMR 6118, Rennes, France \\ c BRGM Water Department, B.P. 6009, 45060 Orléans Cedex, France
}

\begin{abstract}
This paper focuses on the chemical evolution of water during the exploitation of a fractured aquifer in a $\mathrm{NO}_{3}$-rich agricultural environment. During a ten year period, both production rate and chemical parameters were continuously measured in tap water obtained from a deep-water plant in Brittany, France. Changes in $\mathrm{SO}_{4}^{2-}$ and $\mathrm{NO}_{3}^{-}$were observed after pumping was initiated. Nitrate concentration decreased during the first 200 days and then stabilized at $\sim 5 \pm 1 \mathrm{mg} / \mathrm{L}$, while $\mathrm{SO}_{4}^{2-}$ concentration increased rapidly over this period and then showed a steady state increase $(0.01 \mathrm{mg} / \mathrm{L} /$ day $)$. These changes are attributed to the development of equilibrium between the physical flow parameters and the chemical kinetics of autotrophic denitrification processes that occur in the pyrite-bearing fractures.

The chemical characteristics of the groundwaters collected in 18 wells located around the site allow identification of two different areas. One is weakly influenced by pumping and is characterized by high $\mathrm{NO}_{3}^{-}$concentrations and a short residence time. The second area is directly related to the main pumped well, and characterized by reduced $\mathrm{NO}_{3}^{-}$levels combined with an increased $\mathrm{SO}_{4}^{2-}$ production, resulting from the denitrification processes in the pyrite-bearing fractures. Over the last few years, a $\mathrm{SO}_{4}^{2-}$ increase unrelated to denitrification has been recorded in some wells. Based on the $\mathrm{NO}_{3}^{-}, \mathrm{SO}_{4}^{2-}$ and $\mathrm{Fe}$ concentrations, this is attributed to oxidation of $\mathrm{S}$ minerals, coupled to $\mathrm{Fe}^{\mathrm{III}}$ reduction. Exploitation of the aquifer has led to a rapid transfer of the waters within the deep fractures. Their high velocities strongly control the chemical parameters and have led to a redox sequence that has promoted $\mathrm{S}$ oxidation, coupled with (1) $\mathrm{O}_{2},(2) \mathrm{NO}_{3}^{-}$, and (3) $\mathrm{Fe}$ reduction.
\end{abstract}

\footnotetext{
* Corresponding author.

E-mail address: Corinne.Tarits@univ-brest.fr (C. Tarits).
}

\section{Introduction}

Over the past few decades, discharges of $\mathrm{NO}_{3}^{-}$ from drains or shallow wells have been increasing due to anthropogenic inputs (Jordan et al., 1997). 
Correlations between anthropogenic inputs, fertilizer application, cultivation of $\mathrm{N}$-fixing crops, and groundwater and river water pollution have been studied by numerous authors (e.g. Hill, 1978; Osborne and Wiley, 1988; Mason et al., 1990; Jordan and Weller, 1996). The spatial distribution of groundwater quality is not only related to groundwater contamination aspects. It also depends on water pathways, residence time, and thus on the soil and aquifer hydraulic properties (Grambell et al., 1975; Spalding and Exner, 1993; Brenner and Mondok, 1995; Martin et al., 2004). In regions of crystalline rocks such as Brittany in northwestern France, tap water is traditionally supplied from shallow wells or surface water reservoirs. Interest in production requirements from deep-water sources has increased because of growing concern about agricultural groundwater contamination problems. However, the silicate bedrock contains small aquifers that are usually located in the fracture system of the basement. Both large porous fractures and a high connectivity are required for the development of a large and sustainable water resource. Although fractured systems commonly do not provide large water flow, large fractured zones enhance their permeability (Aquilina et al., 2004). Understanding the aquifer behavior is crucial for its management, basically to prevent any possible contamination from the anthropogenic surface activities after several years of exploitation. Understanding the physics and the chemistry of fractured aquifers illustrates several problems that are mainly related to fluid flow heterogeneity and their relation with biochemical processes.

Both $\mathrm{NO}_{3}^{-}$consumption due to biogeochemical processes and long-term changes in $\mathrm{NO}_{3}^{-}$and $\mathrm{SO}_{4}^{2-}$ have been reported in several aquifer studies (Howard, 1985; Kölle et al., 1985; Mariotti, 1986; Mariotti et al., 1988; Frind et al., 1990; Postma et al., 1991; Smith et al., 1991; Engesgaard and Kipp, 1992; Korom, 1992; Böhlke and Denver, 1995; Puckett et al., 1999; Puckett and Cowdery, 2002; Pauwels et al., 2001; Koenig and Liu, 1996). Understanding both $\mathrm{NO}_{3}^{-}$transport through basement fractures and its consumption due to biogeochemical processes within the fractures is a key issue in evaluating the long term effects of $\mathrm{N}$-application on groundwater quality. Nitrate is available from natural sources (nitrification) or as a constituent in fertilizers. Aquifer redox conditions that control $\mathrm{NO}_{3}^{-}$removal and all other redox reactions may be described by characteristic redox species $(\mathrm{C}, \mathrm{N}$,
O, S, Fe, Mn) (Champ et al., 1979; Berner, 1981; Postma et al., 1991; Stumm and Morgan, 1981). When $\mathrm{N}$ removal is associated with $\mathrm{SO}_{4}^{2-}$ production the process involved is biochemical autotrophic denitrification (Stumm and Morgan, 1981; Mariotti, 1986; Rödelsperger, 1989; Pauwels et al., 2000). Even, when low contents of organic material are present either in dissolved or solid forms, chemolithotrophic bacteria such as Thiobacillus denitrificans may use reduced $\mathrm{S}$ compounds such as pyrite to reduce $\mathrm{NO}_{3}^{-}$and produce $\mathrm{SO}_{4}^{2-}$, gaseous $\mathrm{N}_{2}$ and $\mathrm{Fe}^{\mathrm{II}}$ (Rödelsperger, 1989; Frind et al., 1990; Postma et al., 1991; Böttcher et al., 1990). The water chemistry evolution of redox-dependant species depends on both the availability of the electron donors in the solid phase or in the groundwater, and the presence of electron acceptors. Electron acceptors such as $\mathrm{O}_{2}, \mathrm{NO}_{3}^{-}$, and potentially $\mathrm{SO}_{4}^{2-}$ are usually transported by water. The potential electron donors that are thermodynamically able to reduce $\mathrm{NO}_{3}^{-}$are organic matter, pyrite and Fe(II)-silicates (Postma et al., 1991; Chapelle et al., 1995; Tesoriero et al., 2000; Böhlke et al., 2002; Puckett and Cowdery, 2002). In natural systems, Mn(III, IV) and Fe(III)oxides are subject to reductive dissolution. For instance, dissolution of $\mathrm{Fe}$ (III)-oxides is markedly enhanced by reducing agents (Hering and Stumm, 1990). Therefore, $\mathrm{MnO}_{2}$ and $\mathrm{Fe}(\mathrm{III})$-solids may also be associated with the redox processes, although they are solid oxidizers.

In fractured rocks with very low matrix permeability, such as crystalline rocks, fluid flow is often very heterogeneous and located in few fractures (Neretnieks, 1985; Bour and Davy, 1997). Incompatible reactions may occur juxtaposed in the same system, depending on the permeability of the medium (Moncaster et al., 2000). Pumping from a fractured aquifer will force waters through fractures toward the wells and thus change the fluid velocity and possibly the water flow path. In this case, it is difficult to apply classical hydrogeological theories that are based on an equivalent porous medium.

In this paper, new information is provided on the changes observed in groundwater chemical composition, particularly $\mathrm{NO}_{3}^{-}, \mathrm{SO}_{4}^{2-}$ and $\mathrm{Fe}$ contents, which are related to the development of a deep water reservoir in a fractured system at Ploemeur in Brittany, NW France. This paper reviews: (1) the main processes that influence groundwater quality; and (2) the possible relationships that may exist between the chemical composition changes of the 
groundwater and the water fluxes induced by pumping development.

\section{Geological and hydrogeological settings}

The deep-water plant of Ploemeur has been exploited as the principal source of tap water for a medium sized city $(15,000$ inhabitants) since June 20th 1991. Fig. 1(a) shows the study site and a location map of the wells. The annual water production is about $10^{6} \mathrm{~m}^{3}$. The net recharge is about $0.7 \mathrm{~m} / \mathrm{a}$ (Touchard, 1999). The site is located on a $2.5 \mathrm{~km}^{2}$ watershed, with an average elevation of $25 \mathrm{~m}$ above sea level. This area includes three types of land uses: Lorient domestic airport, farms, and the town of Ploemeur. Sixty percent of the watershed surface is dedicated to agricultural land use such as dairy livestock production and cropland (mostly vegetables and corn). Overall, about $50 \mathrm{~kg} \mathrm{~N} /$ ha of fertilizer was applied to the soil across this area in 1995 (Roussel and Gallat, 1996).

The geology of this part of southern Brittany is characterized by the South-Armorican Shear Zone. This structure is a NE trending shear zone that extends for several hundred kilometers along the southern border of French Brittany. The development of this structure was accompanied by intense tectonic activity that strongly fractured the formations. In the study area, there is a flat-lying contact between massive granites and surrounding mica schists. This contact zone consists of alternate subhorizontal units mainly made up of granites, micaschists or pegmatites. These formations are strongly weathered at the surface down to a depth of about $35 \mathrm{~m}$. Below the weathered zone, the rocks show variable degrees of fracturing. The main fracture zones correspond to a major hydraulic path and coincide with a pegmatite-rich area (Fig. 1(b)). The production zone extends perpendicular to the Southern Armorican Shear Zone along a $20^{\circ} \mathrm{N}$ striking fault that crosscuts the older shear structures.

Eighteen boreholes were drilled in the study area in 1990 to a depth of $70-125 \mathrm{~m}$ to find a new reservoir to satisfy the local need for tap water. Three of these boreholes are now pumped wells (solid square in Fig. 1(a)) and the others are used as observation wells. Two shallow boreholes, MF1 and MF2 (35 m depth), are also used as observations wells in the weathered domain (Fig. 1(a)). The local geology was studied from drill cuttings obtained from the 18 boreholes (Fig. 1(a)), and from cross sections exposed along the sea-shore. The schematic representation of six boreholes is presented in Fig. 1b. Tap water has been extracted from one main pumped well, PE since June 1991. During the first 417 days, the tap-water production rate was close to about $80 \mathrm{~m}^{3} / \mathrm{h}$ and then increased to about $120 \mathrm{~m}^{3} / \mathrm{h}$ with the addition of two new pumping wells, F29 and F31. After 417 days, the production was maintained at around $120 \mathrm{~m}^{3} / \mathrm{h}$ with peaks of up to $170 \mathrm{~m}^{3} / \mathrm{h}$ during summer (Fig. 2).

Predicting flow paths and velocities in a fractured medium is difficult due to the unknown complex geometry of the fracture network and the wide range of densities, lengths, and apertures of the fractures (Neretnieks, 1985). Since 1991, when exploitation began, a series of piezometric measurements at different intervals have been made in the 18 wells to construct the 3D piezometric surface of the aquifer. The maximum drawdown depression is located in the pumped well zone and its extension has increased with time, indicating that the local recharge does not balance the pumped volumes.

Constant-rate pumping tests have been performed primarily to study hydraulic properties of the fractured zone on different scales. The analyses focused specifically on the scale dependence of the hydraulic parameters. The area directly connected to the pumped wells, which extends along the $20^{\circ} \mathrm{N}$ striking fault, was about $250 \times 10^{4} \mathrm{~m}^{2}$. Transmissivity remained constant regardless of distance to the pumping well with values around $1.5 \times 10^{-3} \mathrm{~m}^{2} / \mathrm{s}$. The storage coefficient, however, decreased by one order of magnitude with the distance to the well pumped during the hydraulic test. A complete interpretation of these results, incorporating a generalized version of the Theis/Jacob model to non integral flow dimension (Barker, 1988), is presented elsewhere (Le Borgne et al., 2004).

\section{Data collection and experimental methods}

Two different geochemical surveys were performed at the Ploemeur site after groundwater exploitation began:

(1) In the PE pumping well, production rate and electrical conductivity (EC) were recorded, and $\mathrm{NO}_{3}^{-}, \mathrm{Cl}^{-}, \mathrm{SO}_{4}^{2-}$ concentrations and alkalinity were determined every 10 days to monitor the quality of tap water delivered to the 


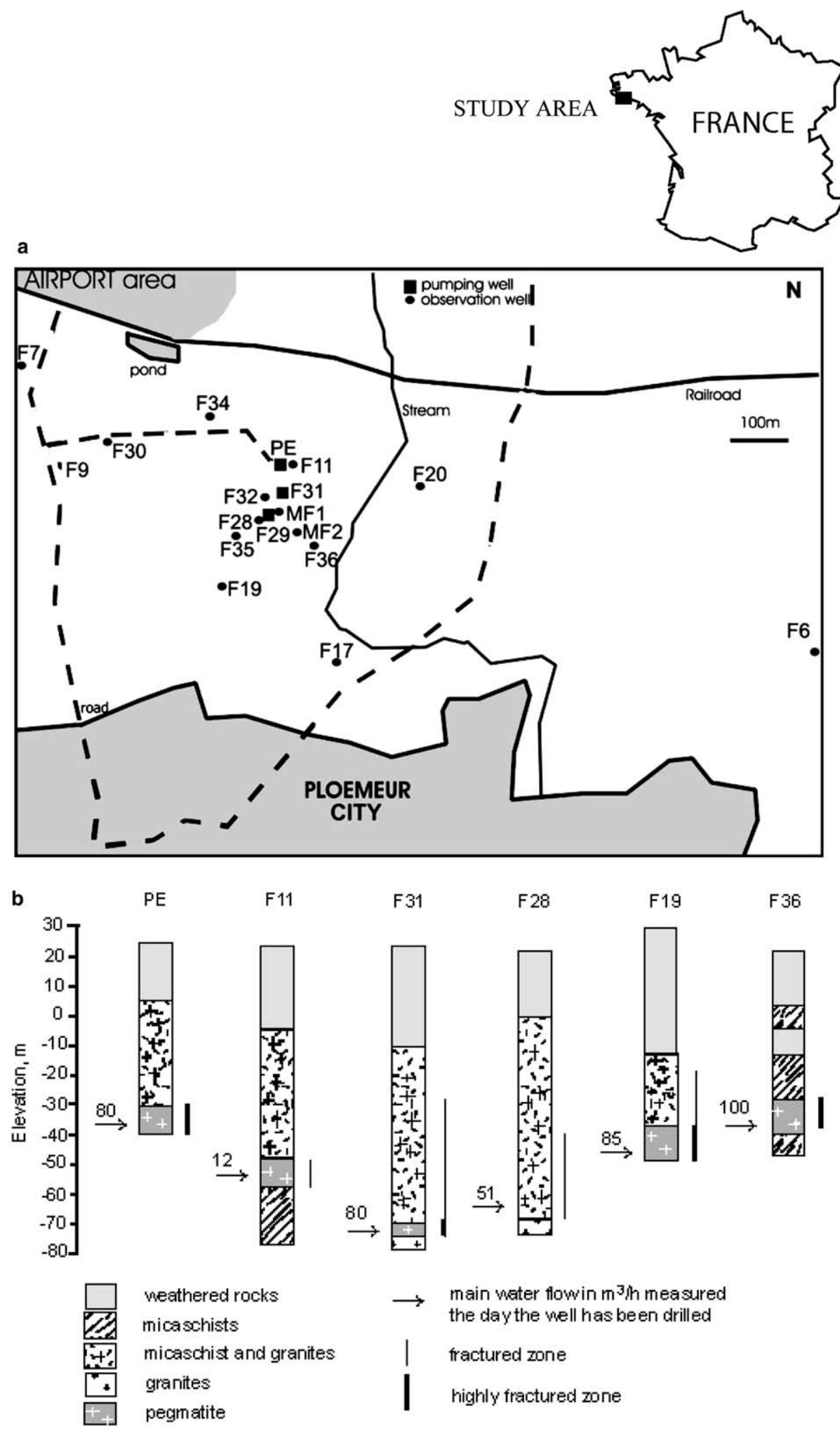

Fig. 1. (a) Pumped wells (solid squares) and observation wells (solid circles) at the Ploemeur site, France. Lorient domestic airport and Ploemeur city are also indicated. (b) Typical geological logs showing units from selected wells. Arrows indicate the location of mean water inflow for each well in $\mathrm{m}^{3} / \mathrm{h}$. Each value of the mean water flow corresponds to a measurement made during drilling. 

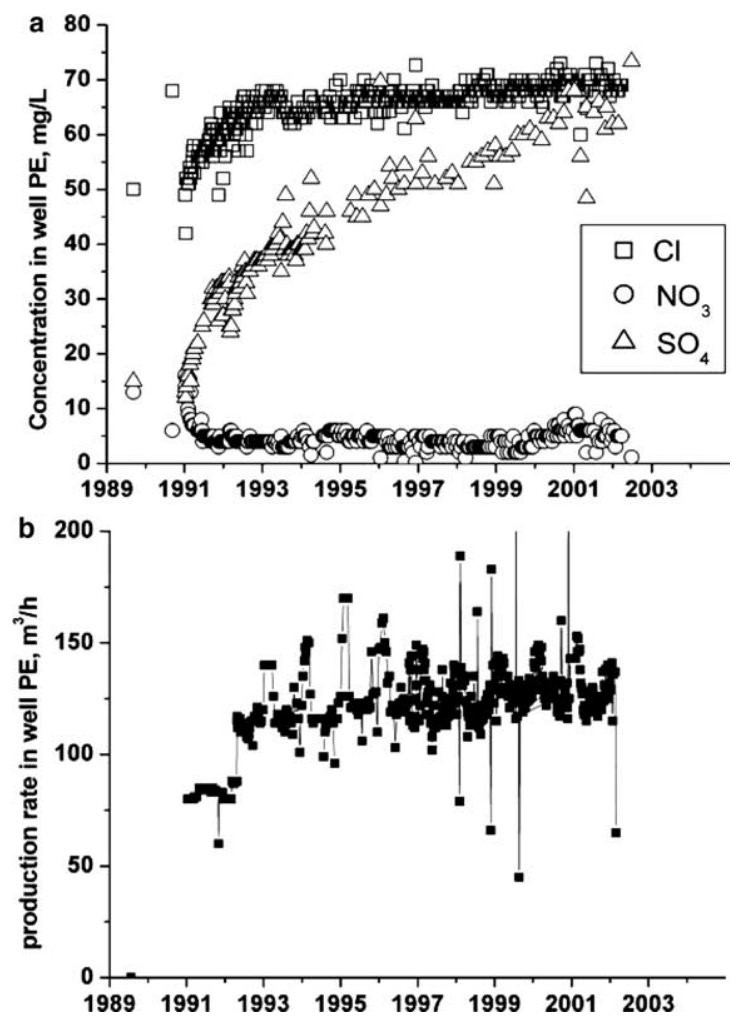

Fig. 2. (a) Concentrations of $\mathrm{Cl}^{-}$(squares), $\mathrm{SO}_{4}^{2-}$ (triangles) and $\mathrm{NO}_{3}^{-}$(circles) in the groundwater extracted from the main pumped well, PE, from February 1991 to September 2002. (b) Production rate of PE from February 1991 to September 2002.

water plant. Five chemical analyses were also made for the major and trace elements in PE between 02/19/91 and 02/06/95.

(2) In 15 wells (which correspond to 29 sites at different depths in the either pumped or observation wells) in the Ploemeur catchment, water samples were collected over 7 field campaigns (from June 1996 until December 2003).

(1) Long-term monitoring: Chemical analyses of $\mathrm{NO}_{3}^{-}, \mathrm{Cl}^{-}, \mathrm{SO}_{4}^{2-}$ concentrations, and Total alkalinity every 10 days and the 5 chemical analyses of PE were performed by the CGI laboratory ("Centre de Génie Industriel", Guidel, France) according to French standard methods, which comply with the French laws on drinking water quality.

(2) Geochemical sampling: The 7 sampling campaigns were carried out in June 1996, September 1996, February 1997, May
1997, October 2001, December 2002 and December 2003. A two-holed automatic groundwater sampler was used to collect water samples at predefined depths in observation wells. Sampling depth corresponds to the location of water inflows identified during drilling and further observed through diagraphy. The sampling depth is indicated in Table 1. For the pumped wells, water was directly sampled at the pump tap. A minimum of two samples were collected at each location. One sample $(250 \mathrm{~mL})$ was collected for major ion analyses. This sample was divided into two sub-samples and filtered on site through a $0.2 \mu \mathrm{m}$ mesh sieve. All samples for cation and trace element analyses were acidified with $2 \mathrm{~mL}$ of $2 \mathrm{~N}$ ultrapure $\mathrm{HNO}_{3}$ and stored in PTFE bottles, rinsed twice with double-distilled acid and in ultrapure water.

Water temperature, $\mathrm{pH}$, and salinity-conductivity were measured in the field at each location. Total alkalinity (Alk.) was determined by $\mathrm{H}_{2} \mathrm{SO}_{4}(0.04 \mathrm{~N})$ titration within a few hours after collection. Electrical conductivity and temperature were measured using a WTW Conductivity Meter LF196, equipped with a TetraCon 96-1.5 electrode. The $\mathrm{pH}$ was measured using a WTW pH 320 instrument, equipped with a pH-combined electrode with integrated temperature sensor, SENTEX 97T. Major ions and selected trace elements were analyzed, several days after each field experiment. $\mathrm{NO}_{3}^{-}, \mathrm{Cl}^{-}, \mathrm{SO}_{4}^{2-}$, and $\mathrm{Br}^{-}$concentrations were measured using ion-chromatography (DIONEX DX-100), and $\mathrm{SiO}_{2}$ and $\mathrm{F}^{-}$by colorimetry (HACH DR-4000 spectrophotometer). Calcium ${ }^{2+}, \mathrm{Mg}^{2+}, \mathrm{Na}^{+}, \mathrm{K}^{+}, \mathrm{Fe}_{\text {total }}$, $\mathrm{Al}_{\text {total }}, \mathrm{Mn}^{2+}, \mathrm{Sr}^{2+}$ and $\mathrm{Ba}^{2+}$ concentrations were measured using an inductively coupled plasma atomic emission spectrometer (ICP-AES) (ISA Jobin-Yvon JY 70 Plus) in the LARAAH laboratory (Laboratoire de Recherches Appliquées Atmosphère-Hydrosphère) for the 1996 and 1997 campaigns, and for the 2001-2003 campaigns using an inductively coupled plasma mass-spectrometer (ICP-MS) (HP-4500) in the Geosciences Laboratory (Bouhnik-Le Coz et al., 2001). All resulting cationanion charge balances are within $10 \%$, with most samples lying within 5\%. Precision based on triplicates is better than $3 \%$, except for alkalinity and $\mathrm{SiO}_{2}$ analyses which were $8 \%$ and $5 \%$, respectively. 


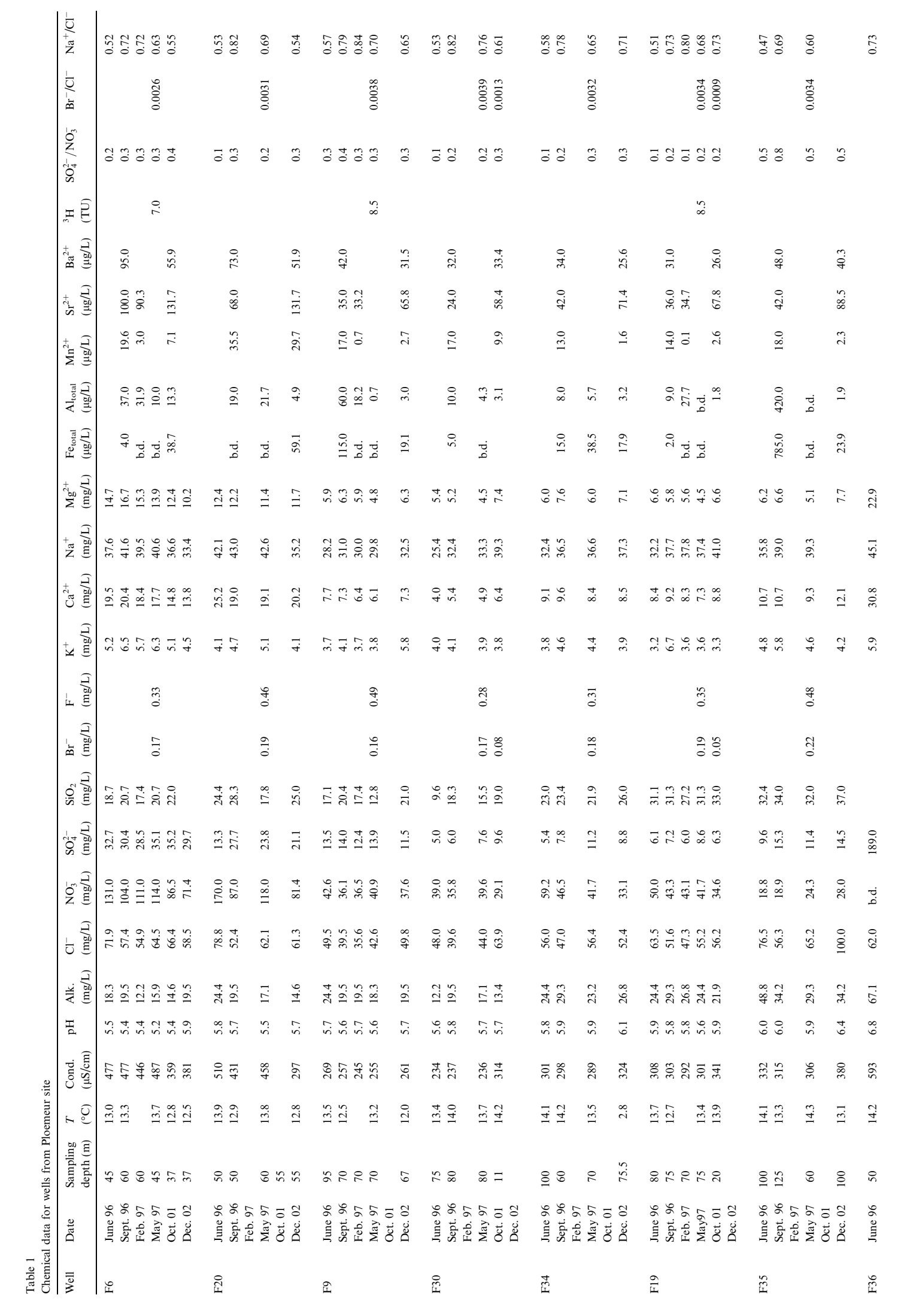




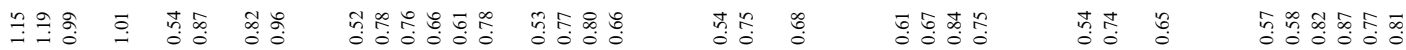
气े
高商

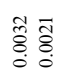
范
$\stackrel{n}{8}$

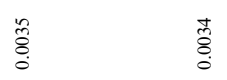

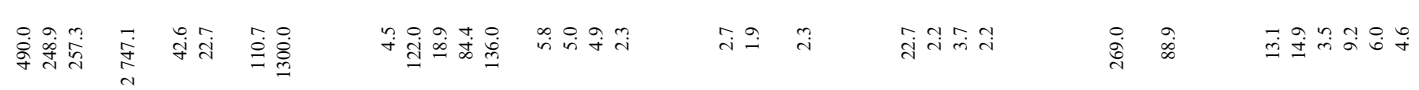

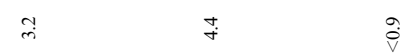

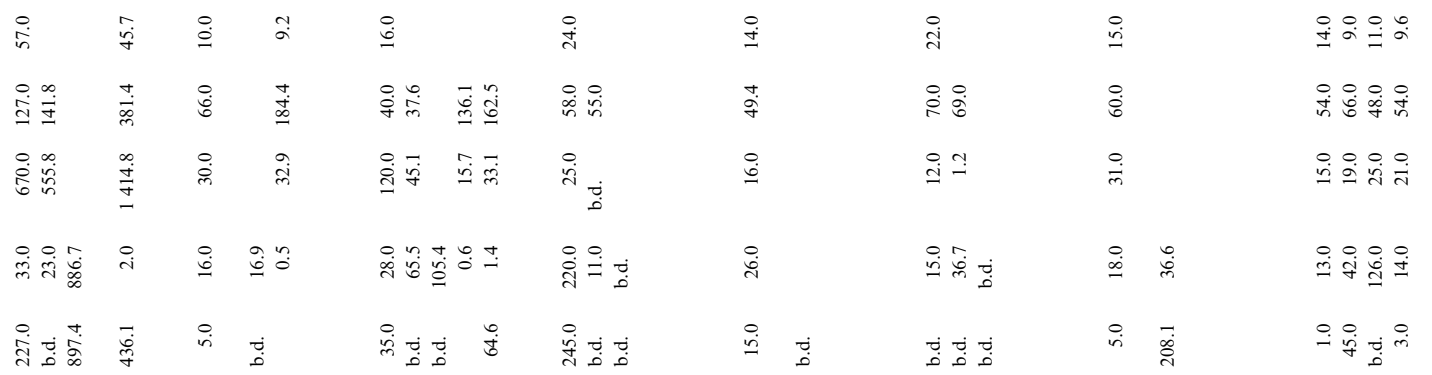

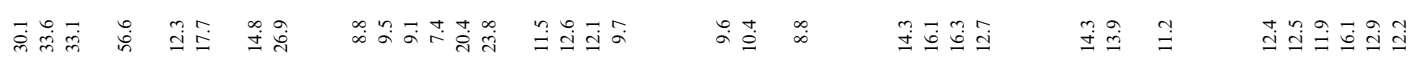

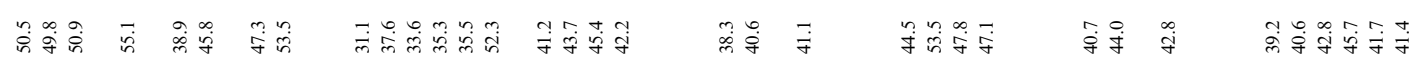

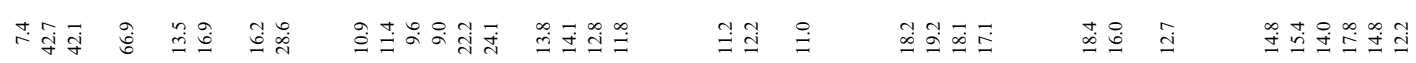

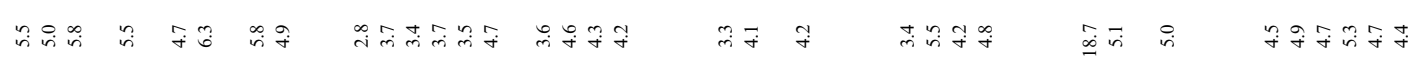

\begin{tabular}{|c|c|c|c|c|c|}
\hline & $\stackrel{8}{\circ}$ & $\stackrel{\infty}{o}$ & 苦 & ?a & : \\
\hline & $\frac{9}{8}$ & 70 & ปี & $\overline{\check{\delta}}$ & สี \\
\hline
\end{tabular}

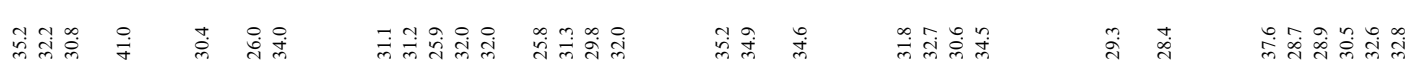

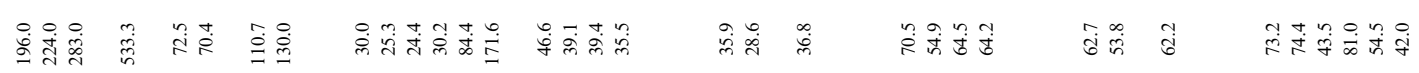

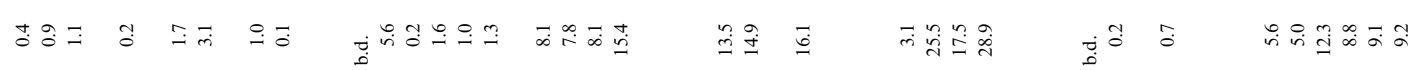

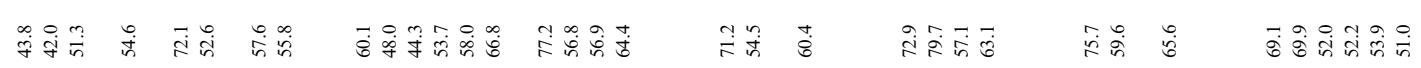

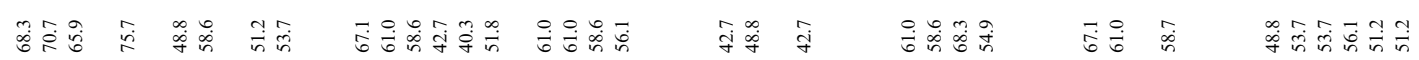

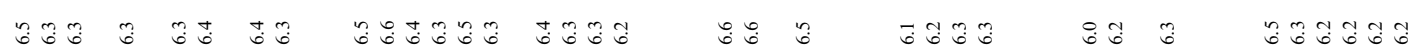

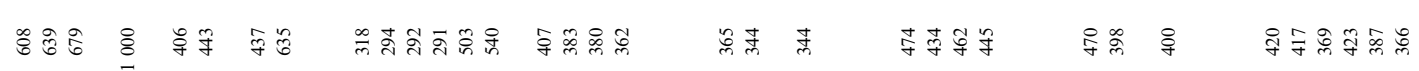

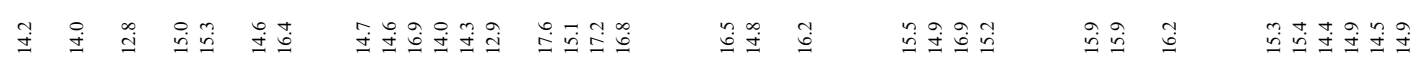

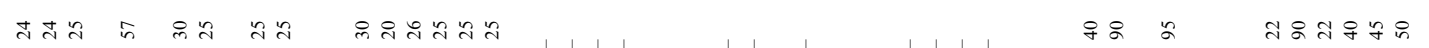

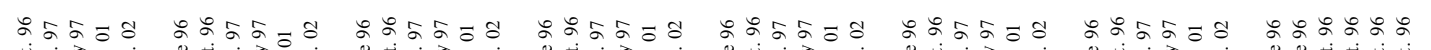

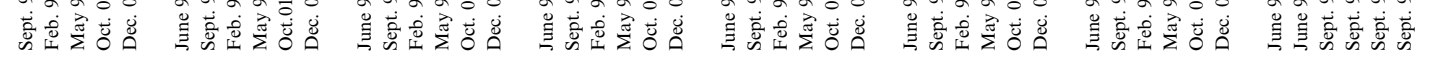
$\overrightarrow{\mathrm{I}}$ 变 $\overline{1}$ กิ I 포 ฐ 
During the May 1997 campaign, a selected set of samples was collected for ${ }^{3} \mathrm{H}$ analyses. Tritium was analyzed at the "Centre de Recherches Géodynamiques" at Thonon-les-Bains by an electrolytic enrichment and the standard method of liquid scintillation counting, with a precision of 0.5 tritium units (TU).

\section{Results}

\subsection{Evolution of the water quality in the pumping well}

The data set allows the distinction of two types of changes: (1) long-term variation of chemical composition; (2) short-term variations affecting $\mathrm{SO}_{4}^{2-}$ and $\mathrm{NO}_{3}^{-}$concentrations and alkalinity, which are linked to rapid changes in the production rate.

(1) Long-term changes: The quality of the groundwater extracted at $\mathrm{PE}$ is of the $\mathrm{Na}-\mathrm{Cl}$ type and has evolved since exploitation began (Table 2). Between 1991 and 2003, electrical conductivity increased by up to $90 \%$, in response to increase of concentrations of all major ion species except $\mathrm{NO}_{3}^{-}$. The increases of $\mathrm{Ca}^{2+}+\mathrm{Mg}^{2+}$ and $\mathrm{SO}_{4}^{2-}+\mathrm{Alk}$ were $91 \%$ and $199 \%$, respectively, and those of $\mathrm{Na}^{+}+\mathrm{K}^{+}$and $\mathrm{Cl}^{-}$were $64 \%$ and $97 \%$, respectively. Furthermore, a $92 \%$ decrease in $\mathrm{NO}_{3}^{-}$concentration was also observed. As illustrated in Fig. 2, the $\mathrm{SO}_{4}^{2-}$ and $\mathrm{NO}_{3}^{-}$variations through time are inversely correlated after pumping initiation. During the initial 158 days, the rate of decrease in $\mathrm{NO}_{3}^{-}$was similar to the increase in $\mathrm{SO}_{4}^{2-}$ at 0.06 and $0.07 \mathrm{mg} / \mathrm{L} /$ day, respectively. After 158 days, the decline in $\mathrm{NO}_{3}^{-}$concentration ended and stabilized at about $5 \pm 1 \mathrm{mg} / \mathrm{L}$, whereas the $\mathrm{SO}_{4}^{2-}$ concentration was still increasing. After 417 days, the increase in $\mathrm{SO}_{4}^{2-}$ concentration also slowed down and reached a steady increase of about $0.01 \mathrm{mg} / \mathrm{L} /$ day.

(2) Short-term variations: Some of the short-term variations were observed at the onset of pumping, whereas others occurred after a change in the pumping rate in the pumped well (PE). Such variations are particularly observable consequent to increase of pumping rate from 80 to $120 \mathrm{~m}^{3} / \mathrm{h}$ after 417 days of exploitation by bringing two new wells (F29 and F31) into production. This induced a decrease in $\mathrm{SO}_{4}^{2-}$ concentration by $8.0 \mathrm{mg} / \mathrm{L}$ along with 
Table 2

Chemical characteristics of water extracted from the main pumped well, PE

\begin{tabular}{|c|c|c|c|c|c|c|c|c|c|c|c|}
\hline & \multicolumn{3}{|l|}{1991} & \multirow{2}{*}{$\frac{1992}{\text { Apr. }}$} & \multirow{2}{*}{$\frac{1995}{\text { Feb. }}$} & \multicolumn{2}{|l|}{1996} & \multicolumn{2}{|l|}{1997} & \multirow{2}{*}{$\frac{2001}{\text { Oct. }}$} & \multirow{2}{*}{$\begin{array}{l}2002 \\
\text { Dec. }\end{array}$} \\
\hline & Feb. & Aug. & Dec. & & & June & Sep. & Feb. & May & & \\
\hline $\mathrm{EC}(\mu \mathrm{S} / \mathrm{cm})$ & 266 & 248 & 275 & 293 & 434 & 453 & 432 & 422 & 420 & 491 & 506 \\
\hline $\mathrm{pH}$ & 6.4 & 6.5 & 6.2 & 6.2 & 6.6 & 6.5 & 6.7 & 6.6 & 6.7 & 6.8 & 7.3 \\
\hline Alkalinity $(\mathrm{mg} / \mathrm{L})$ & 33.0 & 33.6 & 34.5 & 39.0 & 57.0 & 67.1 & 65.9 & 65.9 & 63.4 & 65.9 & 70.2 \\
\hline $\mathrm{Cl}^{-}$ & 50.0 & 53.0 & 57.0 & 61.0 & 65.0 & 83.3 & 64.3 & 61.4 & 72.7 & 64.8 & 98.6 \\
\hline $\mathrm{NO}_{3}^{-}$ & 13.0 & 8.0 & 5.0 & 4.0 & 2.0 & 1.0 & 3.7 & 0.4 & 0.2 & 2.0 & 1.1 \\
\hline $\mathrm{NO}_{2}^{-}$ & 0.04 & b.d. & b.d. & b.d. & b.d. & & & & & & \\
\hline $\mathrm{SO}_{4}^{2-}$ & 15.0 & 19.0 & 26.0 & 31.0 & 46.0 & 69.7 & 54.3 & 54.4 & 62.9 & 48.4 & 73.4 \\
\hline $\mathrm{P}_{2} \mathrm{O}_{5}$ & 0.36 & 0.38 & u.d. & 0.35 & 0.40 & & & & & & \\
\hline $\mathrm{F}^{-}$ & 0.09 & 0.12 & 0.15 & 0.17 & 0.18 & & & & 0.45 & & \\
\hline $\mathrm{Br}^{-}$ & & & & & & & & & 0.25 & 0.19 & \\
\hline $\mathrm{NH}_{4}^{+}$ & b.d. & b.d. & b.d. & b.d. & b.d. & & & & & & \\
\hline $\mathrm{Na}^{+}$ & 33.0 & 33.5 & 36.0 & 38.0 & 42.0 & 43.6 & 48.3 & 84.3 & 47.7 & 51.8 & 54.9 \\
\hline $\mathrm{K}^{+}$ & 3.0 & 3.1 & 2.7 & 2.8 & 4.0 & 3.9 & 6.6 & 5.0 & 5.1 & 3.8 & 4.2 \\
\hline $\mathrm{Ca}^{2+}$ & 7.2 & 7.7 & 8.7 & 10.2 & 14.0 & 15.2 & 16.1 & 14.8 & 15.9 & 18.6 & 18.1 \\
\hline $\mathrm{Mg}^{2+}$ & 6.0 & 6.7 & 7.5 & 8.7 & 13.0 & 14.0 & 16.5 & 14.8 & 13.5 & 16.8 & 17.1 \\
\hline $\mathrm{SiO}_{2}$ & 37.0 & 33.0 & 29.0 & 38.0 & 32.0 & & 26.4 & 28.8 & 29.7 & 34.7 & 33.4 \\
\hline $\mathrm{Fe}_{\text {total }}(\mu \mathrm{g} / \mathrm{L})$ & & & & & & 44.0 & 85.0 & b.d. & b.d. & b.d. & 58.6 \\
\hline $\mathrm{Al}_{\text {total }}$ & & & & 7.8 & & & 66.0 & b.d. & & b.d. & 1.2 \\
\hline $\mathrm{SO}_{4}^{2-} / \mathrm{NO}_{3}^{-}$ & 1.2 & 2.4 & 5.2 & 0.62 & 23.0 & 69.7 & 14.7 & 136.0 & 314.5 & 24.2 & 66.7 \\
\hline $\mathrm{Na}^{+} / \mathrm{Cl}^{-}$ & 0.66 & 0.63 & 0.63 & & 0.65 & 0.52 & 0.75 & 1.37 & 0.66 & 0.80 & 0.56 \\
\hline $\mathrm{Br}^{-} / \mathrm{Cl}^{-}$ & & & & & & & & 0.003 & 0.003 & & \\
\hline
\end{tabular}

Units are $\mathrm{mg} / \mathrm{L}$ unless indicated. The resulting cation-anion charge balances for most samples were within $4 \%$. b.d., below detection limit. Detection limit of $\mathrm{NO}_{2}^{-}$and $\mathrm{NH}_{4}^{+}$is $0.01 \mathrm{mg} / \mathrm{L}$ and $1.0 \mu \mathrm{g} / \mathrm{L}$ for $\mathrm{Fe}_{\text {total }}$ and $\mathrm{Al}_{\text {total }}$.

a small increase in $\mathrm{NO}_{3}^{-}$concentration by $2.0 \mathrm{mg} / \mathrm{L}$. During the following days, the rate of $\mathrm{NO}_{3}^{-}$consumption was once more similar to the $\mathrm{SO}_{4}^{2-}$ production rate $(0.06$ and $0.07 \mathrm{mg} / \mathrm{L} /$ day, respectively). Chloride concentration also shows some variation when pumping rate increases, but the effect is smaller and shorter than for $\mathrm{SO}_{4}^{2-}$ and $\mathrm{NO}_{3}^{-}$.

\subsection{Vertical and spatial distribution of the water quality}

Table 1 presents the chemistry of the groundwaters sampled in the Ploemeur area. Sampling of the wells around the pumping site allows the spatial chemical variations to be characterised. Three groups can be distinguished on the basis of their $\mathrm{NO}_{3}-\mathrm{SO}_{4}$ content (Fig. 3).

Group $I$ is composed of almost $\mathrm{NO}_{3}^{-}$-free waters with high $\mathrm{SO}_{4}^{2-} / \mathrm{NO}_{3}^{-}$ratios and low ${ }^{3} \mathrm{H}$ content ( $<5$ TU). Wells MF1, MF2 and F36 belong to this group. These wells have characteristics similar to the PE pumping well described above.

Group II, which includes wells F6 and F20, is characterized by an extremely high $\mathrm{NO}_{3}^{-}$content $(>100 \mathrm{mg} / \mathrm{L})$, a low $\mathrm{SO}_{4}^{2-} / \mathrm{NO}_{3}^{-}$ratio, and a high ${ }^{3} \mathrm{H}$ content (7 TU in $\mathrm{F} 6$ ).

Group III waters have high $\mathrm{NO}_{3}^{-}$contents $(10$ to $60 \mathrm{mg} / \mathrm{L}$ ) and $\mathrm{SO}_{4}^{2-} / \mathrm{NO}_{3}^{-}$ratios and ${ }^{3} \mathrm{H}$ contents similar to group II. Wells F9, F19, F30, F34 and F35 belong to this group (8.5 TU in $\mathrm{F} 9$, and F19).

The chemistry of the groundwater shows a clear depth zonation during the 96 and 2001 campaigns (Table 1), which correlates with the distribution of the major inflows described above (Fig. 1). The chemical composition of well F28 (Fig. 4), shows large vertical variations that are related to different water inflows over the range of $30-50 \mathrm{~m}$ and in the deeper part of the borehole $(60-80 \mathrm{~m})$. The $\mathrm{NO}_{3}^{-}-\mathrm{SO}_{4}^{2-}$ ratios in all the samples (for the 6 campaigns from 1996 to 2002, Table 1) have a good linear correlation $\left(R^{2}=0.66\right)$ if the extreme point of 


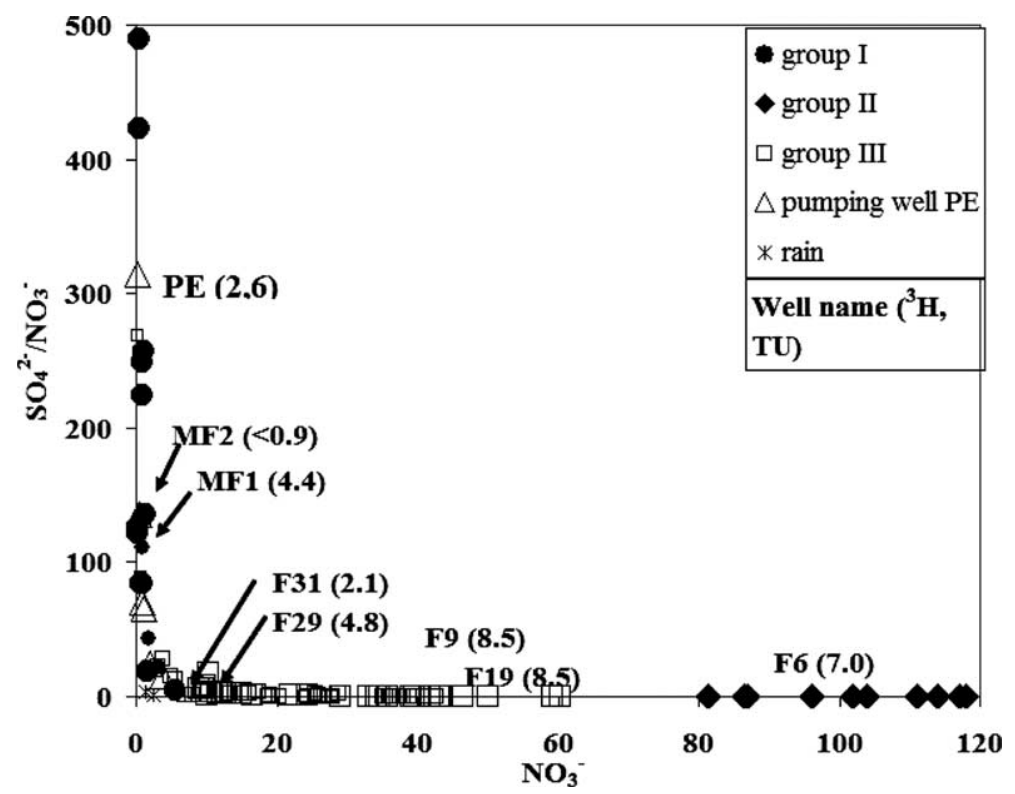

Fig. 3. $\mathrm{SO}_{4}^{2-} / \mathrm{NO}_{3}^{-}$versus $\mathrm{NO}_{3}^{-}$concentration in $\mathrm{mg} / \mathrm{L}$, and ${ }^{3} \mathrm{H}$ data for various sampling sites.
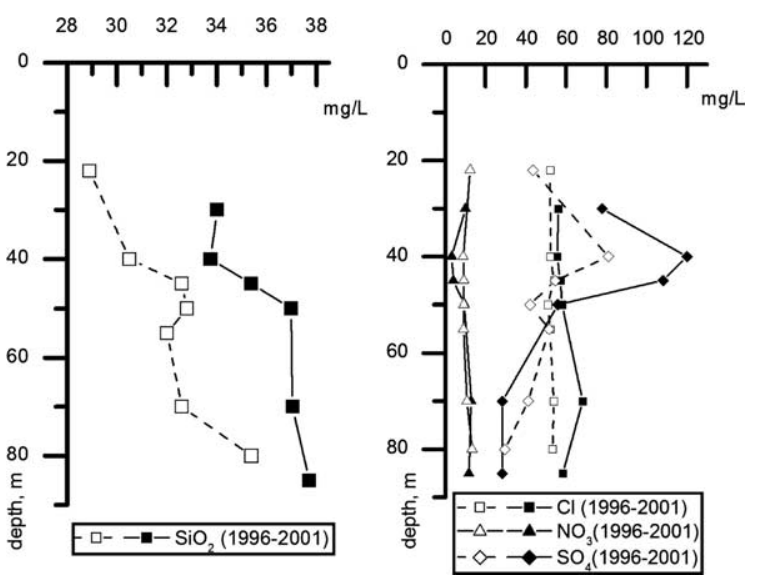

Fig. 4. Vertical distribution of several parameters of the groundwater in well F28 (September 1996 and October 2001 surveys).

December 2002 is omitted. This clearly indicates that encountered waters result from a mixing of two end-members. The first end-member is encountered in the upper part of the borehole and clearly belongs to group I (low $\mathrm{NO}_{3}^{-}$and high $\mathrm{SO}_{4}^{2-}$, low $\mathrm{Cl}^{-}$and high $\mathrm{Na}^{+} / \mathrm{Cl}^{-}$and $\mathrm{SiO}_{2}$ ) exemplified by wells MF1 and MF2. The second end-member is encountered in the lower part of the borehole (below $70 \mathrm{~m}$ ). It does not show any of the characteristics of the group II wells with anthropogenic influence, F6-F20 (high $\mathrm{NO}_{3}^{-}, \mathrm{Cl}^{-}$, low $\mathrm{SiO}_{2}$ concentrations and $\mathrm{Na}^{+} / \mathrm{Cl}^{-}$ratio), and seems to be chemically similar to the group III samples (the western F9, F19, F30, F34 and F35 wells).

The two different groups (I and II) can also be distinguished on the basis of other elements. Group I has relatively high $\mathrm{Na}^{+} / \mathrm{Cl}^{-}$ratios, ranging mainly from 0.5 to 1.2 , high alkalinity $(40-76 \mathrm{mg} / \mathrm{L})$ and $\mathrm{SiO}_{2}$ concentrations $(26-41 \mathrm{mg} / \mathrm{L})$ with respect to Group II for which $\mathrm{Na}^{+} / \mathrm{Cl}^{-}$ratios vary between 0.5 and 0.8 and range of alkalinity is between 12.2 and $24.4 \mathrm{mg} / \mathrm{L}$. $\mathrm{SiO}_{2}$ content are $12-22$ and $17-$ $29 \mathrm{mg} / \mathrm{L}$, respectively. The two groups are also characterised by different chemical carbonate equilibria (Table 3). The $p \mathrm{CO}_{2}$ values computed for group I are in the range expected for waters recharged in soil rich in $\mathrm{CO}_{2}(0.9-3.2 \%)$. Group II shows higher values $(2.1-8.7 \%)$, out of the range for soil-equilibrated waters. The mineral saturation indices (SI) for the waters were computed using PHREEQC (Parkhurst and Appelo, 1999). Calcite saturation indices (SI) show that none of the waters have achieved calcite equilibrium, but group II has much lower SI than group I $(-3.9$ to -3.0 and -2.7 to -1.5 , respectively).

Several wells have shown a major change in their chemical evolution during the studied years. Fig. 5 highlights the difference between groups I and II in their $\mathrm{NO}_{3}^{-}$and $\mathrm{SO}_{4}^{2-}$ evolution. Group III (F19F34-F35-F9-F30) displays very stable concentrations for all the elements analyzed during the sampling period (1991-2003). Group II (F6 and 
Table 3

Computed saturation indexes (SI) of group I and II for the phases $\mathrm{CO}_{2 \text { gas }}$ and calcite

\begin{tabular}{|c|c|c|c|c|}
\hline \multirow[t]{2}{*}{ Well } & \multirow[t]{2}{*}{ Date } & \multirow{2}{*}{$\begin{array}{l}\text { Sampling } \\
\text { depth (m) }\end{array}$} & \multicolumn{2}{|l|}{ SI } \\
\hline & & & $\mathrm{CO}_{2}$ gas & Calcite \\
\hline \multicolumn{5}{|c|}{ Group I } \\
\hline \multirow[t]{6}{*}{ MF1 } & June 96 & 30 & $-1.67(2.14 \%)$ & -2.46 \\
\hline & Sept. 96 & 25 & $-1.69(2.04 \%)$ & -2.21 \\
\hline & Feb. 97 & & & \\
\hline & May 97 & 25 & $-1.76(1.74 \%)$ & -2.30 \\
\hline & Oct. 01 & 25 & $-1.61(2.45 \%)$ & -2.15 \\
\hline & Dec. 02 & & & \\
\hline \multirow[t]{6}{*}{ MF2 } & June 96 & 30 & $-1.73(1.86 \%)$ & -2.19 \\
\hline & Sept. 96 & 20 & $-1.84(1.44 \%)$ & -2.16 \\
\hline & Feb. 97 & 26 & $-1.69(2.04 \%)$ & -2.40 \\
\hline & May 97 & 25 & $-1.73(1.86 \%)$ & -2.67 \\
\hline & Oct. 01 & 25 & $-1.95(1.12 \%)$ & -2.17 \\
\hline & Dec. 02 & 25 & $-1.73(1.86 \%)$ & -2.32 \\
\hline \multirow[t]{6}{*}{ F36 } & June 96 & 50 & $-2.05(0.89 \%)$ & -1.55 \\
\hline & Sept. 96 & 24 & $-1.75(1.78 \%)$ & -1.78 \\
\hline & Feb. 97 & 24 & $-1.53(2.95 \%)$ & -1.91 \\
\hline & May 97 & 25 & $-1.56(2.75 \%)$ & -1.97 \\
\hline & Oct. 01 & & & \\
\hline & Dec. 02 & 57 & $-1.49(3.23 \%)$ & -1.83 \\
\hline \multicolumn{5}{|c|}{ Group II } \\
\hline \multirow[t]{6}{*}{ F6 } & June 96 & 45 & $-1.31(4.90 \%)$ & -3.55 \\
\hline & Sept. 96 & 60 & $-1.17(6.76 \%)$ & -3.61 \\
\hline & Feb. 97 & 60 & $-1.37(4.27 \%)$ & -3.82 \\
\hline & May 97 & 45 & $-1.06(8.71 \%)$ & -3.93 \\
\hline & Oct. 01 & 37 & $-1.30(5.01 \%)$ & -3.85 \\
\hline & Dec. 02 & 37 & $-1.68(2.09 \%)$ & -3.26 \\
\hline \multirow[t]{6}{*}{ F20 } & June 96 & 50 & $-1.48(3.31 \%)$ & -3.00 \\
\hline & Sept. 96 & 50 & $-1.45(3.55 \%)$ & -3.36 \\
\hline & Feb. 97 & & & \\
\hline & May 97 & 60 & $-1.33(4.68 \%)$ & -3.56 \\
\hline & Oct. 01 & & & \\
\hline & Dec. 02 & 55 & $-1.63(2.34 \%)$ & -3.37 \\
\hline
\end{tabular}

Computations were performed using the PHREEQC thermodynamic data base (Parkhurst and Appelo, 1999).

F20 wells with anthropogenic influence) always shows very high but decreasing $\mathrm{NO}_{3}^{-}$concentrations (Fig. 5). These wells represent the western part of the aquifer where agricultural influence is important. The decrease observed in $\mathrm{NO}_{3}^{-}$concentration suggests a recent lower anthropogenic pressure in this zone. Group I (F36, MF1, MF2 wells) shows a clear increase in the $\mathrm{SO}_{4}^{2-} / \mathrm{NO}_{3}^{-}$ratio during the last sampling campaigns. The range of this increase varies among the wells by a factor of 2 for MF2 to about a factor of 10 for F36 and MF1. The evolution described for F36, MF1 and MF2 wells is also seen in the pumped well PE.
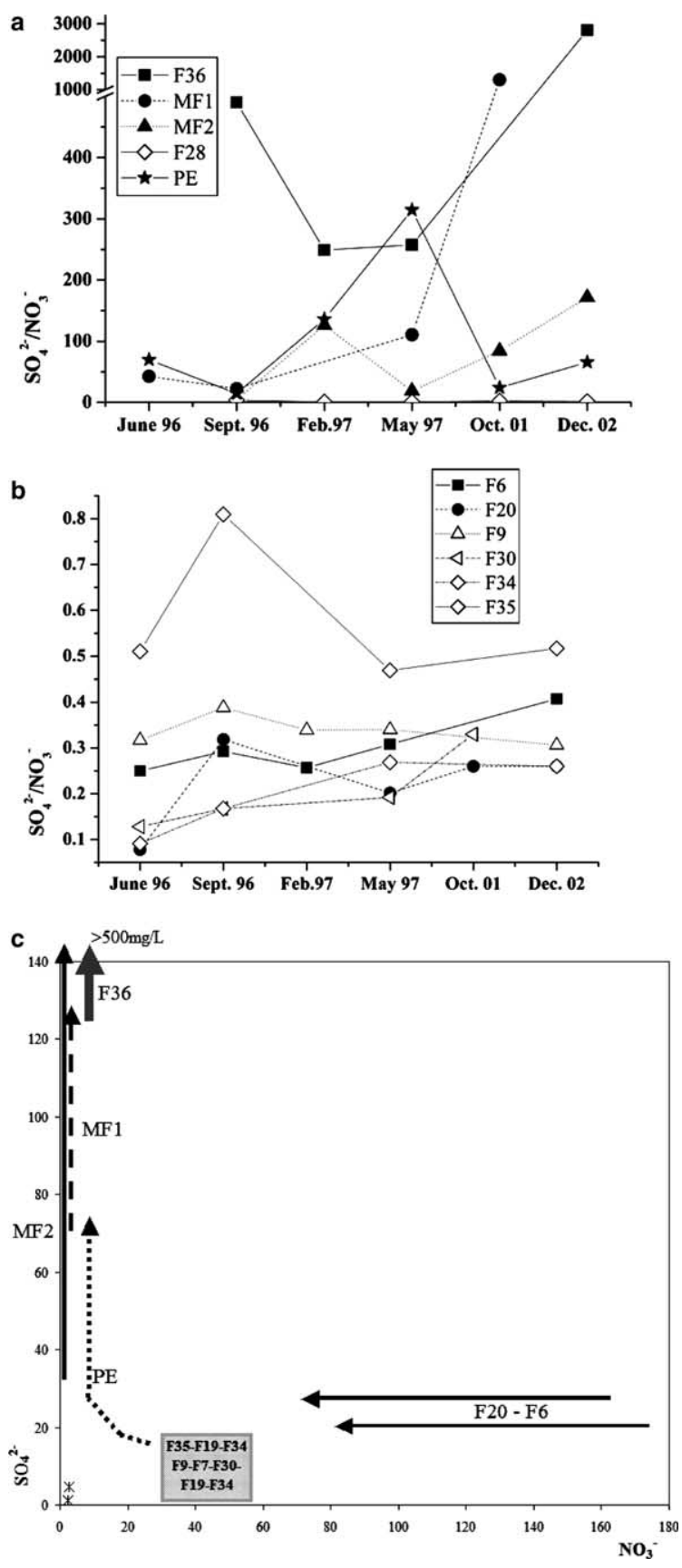

Fig. 5. (a) Evolution of $\mathrm{SO}_{4}^{2-} / \mathrm{NO}_{3}^{-}$ratio for group I with time. (b) Evolution of $\mathrm{SO}_{4}^{2-} / \mathrm{NO}_{3}^{-}$ratio for groups II and III with time. (c) Evolution diagram for $\mathrm{SO}_{4}^{2-} / \mathrm{NO}_{3}^{-}$in some wells. Stars represents rain water. Units are $\mathrm{mg} / \mathrm{L}$.

A hydrochemical synthesis of the vertical and spatial concentrations is presented in Fig. 6. Anthropogenic sources are spatially distributed with high loads in the eastern zone (group II). Within that area, flows of anthropogenic influenced waters 


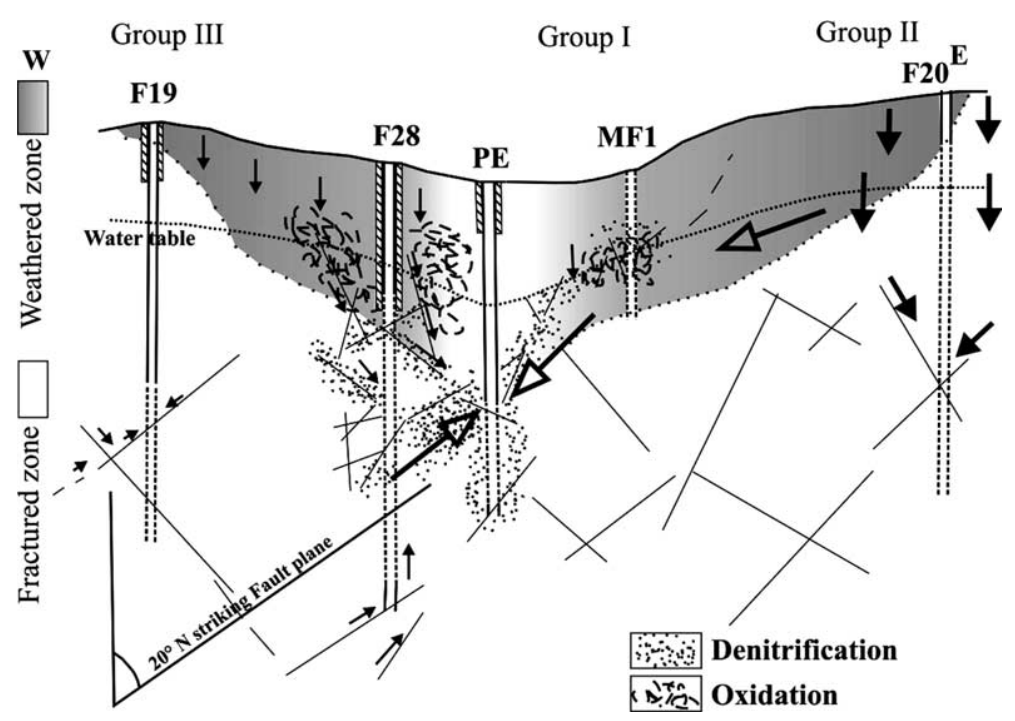

Fig. 6. Hydrogeochemical model of the Ploemeur site.

cross the weathered part of the aquifer rapidly (high ${ }^{3} \mathrm{H}$ concentrations, see discussion) and circulate in the fractures. Fluxes and velocities are much more limited in the western part (group III) and the chemical composition is stable with intermediate $\mathrm{NO}_{3}^{-}$ concentrations compared to groups I and II. In the vicinity of the pumping well, three different kinds of fluxes are observed: (1) Deep fluxes from the eastern part of the aquifer (such as the deeper part of well F28) with medium $\mathrm{SO}_{4}^{2-}$ and $\mathrm{NO}_{3}^{-}$concentrations such as those in group III. (2) Upper fluxes of water characterised by high $\mathrm{SO}_{4}^{2-} / \mathrm{NO}_{3}^{-}$ ratios such as those observed in group II, which originate mainly from the weathered part of the aquifer, along the N20 and N150 fault (as observed in the upper part of F28). (3) Waters from the PE pumping well which evolved during exploitation from the group III composition towards high $\mathrm{SO}_{4}^{2-} / \mathrm{NO}_{3}^{-}$ratios, although lower than those of group II.

\section{Discussion}

\subsection{Origin of the chemical groups and mixing processes}

All the wells sampled at the Ploemeur site show limited variations of some major element concentrations, either in space or time $\left(\mathrm{Cl}^{-}\right.$concentration has an average value of $58 \pm 10.5 \mathrm{mg} / \mathrm{L}, \mathrm{SiO}_{2}: 28.6 \pm$ $6.6 \mathrm{mg} / \mathrm{L}, \quad \mathrm{K}^{+}: \quad 4.6 \pm 1.8 \mathrm{mg} / \mathrm{L}, \quad \mathrm{Na}^{+}: \quad 40.5 \pm 6.2$ $\mathrm{mg} / \mathrm{L}$ and $\left.\mathrm{Mg}^{2+}: 12.6 \pm 8.0 \mathrm{mg} / \mathrm{L}\right)$. Only $\mathrm{NO}_{3}^{-}$and
$\mathrm{SO}_{4}^{2-}$ and, to a lesser extent, alkalinity and $\mathrm{Ca}^{2+}$ content show great amplitude variations. As seen in Fig. 3, three groups of water have been distinguished based only on their $\mathrm{NO}_{3}^{-}$and $\mathrm{SO}_{4}^{2-}$ contents. The high $\mathrm{NO}_{3}^{-}$content in group II waters indicates high anthropogenic loads from agriculture. Moreover, group II waters have high ${ }^{3} \mathrm{H}$ concentrations. The present ${ }^{3} \mathrm{H}$ background level in precipitation is in the order of 5-12 TU (IAEA, 2004). The high ${ }^{3} \mathrm{H}$ concentrations are thus interpreted as an indication of a recent recharge and the short residence time of groundwater. The lower $\mathrm{Na}^{+} / \mathrm{Cl}^{-}$ratios of group II with respect to that of groups I and III may be related to agricultural sources such as fertilizers $(\mathrm{KCl})$ or cattle manure. Wells MF1, MF2 and F36 (group I) have high $\mathrm{SO}_{4}^{2-}$ and low $\mathrm{NO}_{3}^{-}$concentrations but ${ }^{3} \mathrm{H}$ contents are lower. The ${ }^{3} \mathrm{H}$ contents, closer to the present background level, could indicate a very recent recharge or a mixing between recent water and waters older than 1950. The occurrence of a sample showing tritium below detection limit and low ${ }^{14} \mathrm{C}$ activities (Touchard, 1999) strongly supports the second hypothesis. It indicates that these waters are less influenced by anthropogenic sources, because recharge occurred partly before agricultural developments of the study area. This interpretation is also supported by the negative-correlation between the ${ }^{3} \mathrm{H}$ data and $\mathrm{SiO}_{2}$ concentration which is indicative of a higher water-rock interaction degree due to a longer residence time. The group III waters, which show no temporal variation of 
the $\mathrm{NO}_{3}^{-}$and $\mathrm{SO}_{4}^{2-}$ concentrations and moderate $\mathrm{NO}_{3}^{-}$concentrations as compared to group II are less influenced by contamination than group II. They are thought to represent the "original" composition of the aquifer water, before pumping started inducing mixing with the weathered compartment and a chemical evolution of the pumped water.

The evolution of the pumping well (PE) might also be partly related to time-mixing processes of waters of different types, independently of the chemical evolution of components such $\mathrm{NO}_{3}^{-}$and $\mathrm{SO}_{4}^{2-}$. The changes in the $\mathrm{Na}^{+} / \mathrm{Cl}^{-}$ratio and $\mathrm{SiO}_{2}$ contents suggest an evolution of the pumped groundwater evolved from group I (MF1-MF2) waters towards group II (F6-F20) waters, but with chemical modification of their $\mathrm{NO}_{3}^{-}$and $\mathrm{SO}_{4}^{2-}$ contents through biochemical processes (see below).

The decrease of $\mathrm{NO}_{3}^{-}$concentration with depth is due partly to mixing with older waters and redox processes such as denitrification. Despite the occurrence of water with $\mathrm{NO}_{3}^{-}$concentration, varying from $<1$ up to $150 \mathrm{mg} / \mathrm{L}$, a vertical relationship between the chemical composition of groundwater and the structure of the aquifer does not apply at Ploemeur. Groundwaters of wells F6 and F20 (group II), which are located in the eastern part of the pumping site in a topographic high, are highly contaminated by $\mathrm{NO}_{3}^{-}$even though the sampling depth lies in the fissured part of the aquifer (tubing in F20 is open from 11 to $82 \mathrm{~m}$ and, from 10 to $50 \mathrm{~m}$ in F6). In contrast, wells MF1 and MF2 (group I), with low $\mathrm{NO}_{3}^{-}$concentrations, are short wells $(<35 \mathrm{~m})$ located entirely in the weathered part of the aquifer. Moreover, although well F28 has different water quality according to sampling depth, the vertical stratification differs from that expected. At low depth, the waters from the upper part of well F28 $(<50 \mathrm{~m})$ have very low $\mathrm{NO}_{3}^{-}$content and are representative of group I, whereas with depth, $\mathrm{NO}_{3}^{-}$concentrations increase and the deeper inflows $(>70 \mathrm{~m})$ belong to group III.

Actually, water type occurrence is somewhat related to geographic location, induced by the tectonic setting of the area. Despite a variable intensity of anthropogenic impact in the eastern and western parts of the study area, $\mathrm{NO}_{3}^{-}$contaminated waters showing short residence times and low $\mathrm{SO}_{4}^{2-}$ concentration are encountered in both the weathered and in the deep fractured compartment. Conversely, waters with low $\mathrm{NO}_{3}^{-}$content and long residence time can be found along the N20 (and conjugate N150) fault axis, either in the upper weathered part or in the fractured zone of the aquifer, close to the pumping well.

Furthermore, the pumping seems to induce a change in the type of the waters produced from the fault related group I (MF1-MF2) towards the chemically modified group II type (F6-F20), which is influenced by anthropogenic activity.

\subsection{Evidence for in situ nitrate and iron reduction processes}

As shown above, $\mathrm{NO}_{3}^{-}$and $\mathrm{SO}_{4}^{2-}$ are the species with the most variable concentration at the Ploemeur site. Within such a context, these species are mainly affected by redox microbial processes. Stumm and Morgan (1981) describe the sequence of microbiologically mediated redox processes (Table 4). This sequence has already been observed in natural environments (Postma et al., 1991; Appelo and Postma, 1993; Chapelle et al., 1995; Tesoriero et al., 2000; Böhlke et al., 2002; Puckett and Cowdery, 2002). In those cases, when organic matter has been consumed or when it has low reactivity, reduced minerals such as pyrite may serve as electron donors. In the anoxic zone, $\mathrm{NO}_{3}^{-}$is then

Table 4

Sequence of redox reactions with decreasing redox potential (from Stumm and Morgan, 1981) ${ }^{\mathrm{a}}$

\begin{tabular}{|c|c|c|c|}
\hline Reaction & Redox couples & Equation & $\Delta G_{0}(\mathrm{KJ} / \mathrm{eq})$ \\
\hline Oxygen reduction & $\mathrm{O}_{2} / \mathrm{H}_{2} \mathrm{O}\left\langle\mathrm{CH}_{2} \mathrm{O}\right\rangle / \mathrm{CO}_{2}$ & $\mathrm{CH}_{2} \mathrm{O}_{2}+\mathrm{O}_{2} \rightarrow \mathrm{CO}_{2}+\mathrm{H}_{2} \mathrm{O}$ & -125 \\
\hline \multicolumn{4}{|l|}{ Denitrification } \\
\hline Heterotrophic & $\mathrm{NO}_{3} / \mathrm{N}_{2}\left\langle\mathrm{CH}_{2} \mathrm{O}\right\rangle / \mathrm{CO}_{2}$ & $\mathrm{CH}_{2} \mathrm{O}+4 / 5 \mathrm{NO}_{3}^{-}+4 / 5 \mathrm{H}^{+} \rightarrow \mathrm{CO}_{2}+2 / 5 \mathrm{~N}_{2}+7 / 5 \mathrm{H}_{2} \mathrm{O}$ & -119 \\
\hline Autotrophic ${ }^{\mathrm{a}}$ & $\mathrm{NO}_{3} / \mathrm{N}_{2} \mathrm{FeS}_{2} / \mathrm{Fe}^{2+}$ & $5 \mathrm{FeS}_{2}+14 \mathrm{NO}_{3}^{-}+4 \mathrm{H}^{+} \rightarrow 7 \mathrm{~N}_{2}+10 \mathrm{~S}_{4}^{2-}+5 \mathrm{Fe}^{2+}+2 \mathrm{H}_{2} \mathrm{O}$ & -85 \\
\hline Manganese reduction & $\mathrm{MnO}_{2} / \mathrm{Mn}^{2+}\left\langle\mathrm{CH}_{2} \mathrm{O}\right\rangle / \mathrm{CO}_{2}$ & $\mathrm{CH}_{2} \mathrm{O}+2 \mathrm{MnO}_{2}+4 \mathrm{H}^{+} \rightarrow 2 \mathrm{Mn}^{2+}+3 \mathrm{H}_{2} \mathrm{O}+\mathrm{CO}_{2}$ & -56 \\
\hline Iron reduction & $\mathrm{Fe}(\mathrm{OH})_{3} / \mathrm{Fe}^{2+}\left\langle\mathrm{FeS}_{2}\right\rangle / \mathrm{SO}_{4}$ & $\mathrm{FeS}_{2}+14 \mathrm{Fe}(\mathrm{OH})_{3}+26 \mathrm{H}^{+} \rightarrow 15 \mathrm{Fe}^{2+}+2 \mathrm{SO}_{4}^{2-}+34 \mathrm{H}_{2} \mathrm{O}$ & -55 \\
\hline Iron reduction & $\mathrm{Fe}(\mathrm{OH})_{3} / \mathrm{Fe}^{2+}\left\langle\mathrm{CH}_{2} \mathrm{O}\right\rangle / \mathrm{CO}_{2}$ & $\mathrm{CH}_{2} \mathrm{O}+4 \mathrm{Fe}(\mathrm{OH})_{3}+8 \mathrm{H}^{+} \rightarrow 4 \mathrm{Fe}^{2+}+11 \mathrm{H}_{2} \mathrm{O}+\mathrm{CO}_{2}$ & -40 \\
\hline Sulfate reduction & $\mathrm{SO}_{4} / \mathrm{HS}\left\langle\mathrm{CH}_{2} \mathrm{O}\right\rangle / \mathrm{CO}_{2}$ & $\mathrm{CH}_{2} \mathrm{O}+1 / 2 \mathrm{SO}_{4}^{2-}+1 / 2 \mathrm{H}^{+} \rightarrow 1 / 2 \mathrm{HS}^{-}+\mathrm{H}_{2} \mathrm{O}+\mathrm{CO}_{2}$ & -25 \\
\hline Methanogenesis & $\mathrm{CO}_{2} / \mathrm{CH}_{4}\left\langle\mathrm{CH}_{2} \mathrm{O}\right\rangle / \mathrm{CO}_{2}$ & $\mathrm{CH}_{2} \mathrm{O}+1 / 2 \mathrm{CO}_{2} \rightarrow 1 / 2 \mathrm{CH}_{4}+\mathrm{CO}_{2}$ & -23 \\
\hline
\end{tabular}

${ }^{\text {a }}$ According to Pauwels et al. (2000). 
consumed through autotrophic denitrification (Table 4) and both $\mathrm{SO}_{4}^{2-}$ and $\mathrm{Fe}^{2+}$ concentration increase. Ferrous iron may be subsequently oxidized to $\mathrm{Fe}^{(\mathrm{III})}$ and precipitate as Fe-oxides such as $\mathrm{FeOOH}$. Waters of group II and III have high $\mathrm{NO}_{3}^{-}$concentration and low $\mathrm{SO}_{4}^{2-}$ concentration. According to the sequence described above, the redox conditions should remain oxidizing because high concentrations of $\mathrm{NO}_{3}^{-}$indicate that $\mathrm{NO}_{3}^{-}$is not being used as an electron acceptor. This hypothesis is confirmed by relatively low $\mathrm{Fe}$ and $\mathrm{Mn}$ concentrations. On the other hand group I waters have high $\mathrm{SO}_{4}^{2-}$ concentrations and a lack of $\mathrm{NO}_{3}^{-}$. In view of the present agricultural activities in the area, lack of contamination must be dismissed even if contribution of waters recharged before 1950 has been evidenced. Observation of reduced inorganic $\mathrm{S}$ minerals (pyrite) along the fracture planes in the granite (N20 and N150 fault axis) of the Ploemeur area and increasing $\mathrm{SO}_{4}^{2-}$ concentration indicate that autotrophic denitrification must be active and partly explain the lower $\mathrm{NO}_{3}^{-}$concentrations. Low concentrations of organic matter have been measured in the Ploemeur area at all depths (Touchard, 1999), which agrees with the results from similar watersheds (Martin, 2003). It can be considered that in the Ploemeur site denitrification can be mainly autotrophic and only to a lesser extent heterotrophic. An electron balance has been used and the results for the groundwaters collected during the September 1997 campaign have been published in Touchard, 1999. The conclusions were that in the hydrosystem of Ploemeur, the principal $\mathrm{e}^{-}$ donors were $\mathrm{CH}_{2} \mathrm{O}$ and $\mathrm{FeS}_{2}$. The contribution of $\mathrm{CH}_{2} \mathrm{O}$ was comparable in all the studied groundwater samples (groups I, II, and III). The influence of the oxidation process of $\mathrm{FeS}_{2}$ was not important in the two groups I and III but it was predominant in the group II.

In the Ploemeur site, denitrified waters have higher $\mathrm{pH}$ and alkalinity, as well as higher $\mathrm{Ca}^{2+}$ and $\mathrm{Mg}^{2+}$ content than $\mathrm{NO}_{3}^{-}$contaminated waters. However, no increase in $p \mathrm{CO}_{2}$ is noticed (Table 3). The combining of calcite and/or a magnesian mineral dissolution, induced by the acidity generated by $\mathrm{Fe}^{(\mathrm{II})}$ oxidation might have caused such a chemical evolution.

The chemical composition of the water in the PE well, 6 months before pumping (Fig. 2a) is very close to group III presented in the results section. It seems that this water type represents most of the aquifer "original" composition before pumping started, at least for the pumping site and the eastern part of the investigated area. At the onset of the pumping and 417 days later, when the pumping rate is increased by the addition of pumping in F29 well, a rapid evolution of $\mathrm{NO}_{3}^{-}$and $\mathrm{SO}_{4}^{2-}$ is observed. After about 200 days, the evolution slows down and a steady increase of $\mathrm{SO}_{4}^{2-}(0.01 \mathrm{mg} / \mathrm{L} /$ day $)$ is observed for several years, while $\mathrm{NO}_{3}^{-}$concentration remains constant. Fig. 7 compares the evolution of $\mathrm{NO}_{3}-\mathrm{SO}_{4}$ concentration of pumped water with theoretical autotrophic denitrification of waters containing initially 22,50 and $120 \mathrm{mg} / \mathrm{L} \mathrm{NO}_{3}^{-}$. When pumping starts the $\mathrm{NO}_{3}-\mathrm{SO}_{4}$ relation is close to the stoichiometry of the autotrophic denitrification

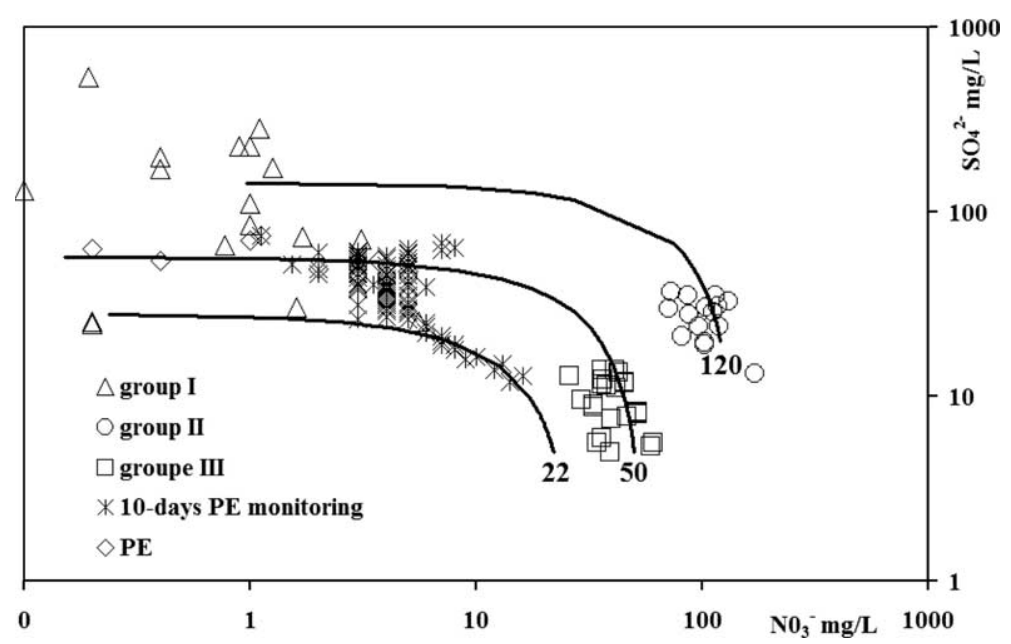

Fig. 7. $\mathrm{SO}_{4}^{-} \mathrm{NO}_{3}$ diagram and chemical pathways. Black curves represents autotrophic denitrification for an initial $\mathrm{NO}_{3}^{-}$content of 22,50 and $120 \mathrm{mg} / \mathrm{L}$. 
of a water containing $22 \mathrm{mg} / \mathrm{L}$ of $\mathrm{NO}_{3}^{-}$. However after several weeks, points deviate from this stoichiometric line, and when pumping flow increases 417 days after the beginning of pumping, chemical composition is in agreement with the stoichiometric denitrification of water, with an initial $\mathrm{NO}_{3}^{-}$concentration of about $50 \mathrm{mg} / \mathrm{L}$. Quite soon, the reaction is limited since $\mathrm{NO}_{3}^{-}$concentration never decreases below $5 \mathrm{mg} / \mathrm{L}$ and a steady state appears. As denitrification is not an ubiquitous process within the aquifer and is particularly active along the N20 and $\mathrm{N} 150$ fault axis, significant steady state $\mathrm{NO}_{3}^{-}$ concentration could also result from the contribution of contaminated water flowing only through fracture/fissures without any denitrifying properties. However, the extremely low $\mathrm{NO}_{3}^{-}$variation $(4.2 \pm 1.2 \mathrm{mg} / \mathrm{L}$ during the last $7 \mathrm{a})$ in PE although pumping rate varies with time supports a physicochemical control rather than mixing processes.

PE waters have much lower Fe concentrations than group III. This indicates Fe-oxide precipitation after the autotrophic denitrification process.

Temporal evolution of chemical composition is not restricted to pumping wells, and high $\mathrm{SO}_{4}^{2-}$ concentration increase versus time has been reported in samples collected in the denitrifying part of the aquifer (group I - wells MF1, MF2 and F36); which needs to be highlighted (Fig. 5(c) and 7). Actually, these concentrations cannot be attributed to denitrification of highly $\mathrm{NO}_{3}^{-}$contaminated water. $\mathrm{SO}_{4}^{2-}$ concentration, up to $500 \mathrm{mg} / \mathrm{L}$ derived from denitrification, implies initial $\mathrm{NO}_{3}^{-}$concentrations of $400 \mathrm{mg} / \mathrm{L}$, and significant concomitant increase of other ions like $\mathrm{Cl}^{-}$would have been observed which is not the case.

A reaction which has not been reported in groundwaters but which is common in acid mine drainage is oxidation of pyrite by dissolved $\mathrm{Fe}^{(\mathrm{III})}$ according to the reaction (Stumm and Morgan, 1981):

$\mathrm{FeS}_{2}+14 \mathrm{Fe}^{3+}+8 \mathrm{H}_{2} \mathrm{O}=15 \mathrm{Fe}^{2+}+2 \mathrm{SO}_{4}^{2-}+16 \mathrm{H}^{+}$

High $\mathrm{SO}_{4}^{2-}$ concentrations associated with high $\mathrm{Fe}^{2+}$ and $\mathrm{Mn}^{2+}$ contents in wells F36, MF1 and MF2 supports this interpretation. Oxidation of pyrite by $\mathrm{Fe}^{3+}$ supplied by the denitrification reaction is however not sufficient to explain the observed $\mathrm{SO}_{4}^{2-}$. Ferric iron must be supplied by dissolution of any solid $\mathrm{Fe}(\mathrm{OH})_{3}$. In an abandoned and sealed mine, such a supply by dissolution may explain the production of mine drainage where $\mathrm{O}_{2}$ supply is cut off completely (Webb and Sasowsky, 1994). In the present case, the dissolving $\mathrm{Fe}(\mathrm{OH})_{3}$ is supposed to be the by-product of the denitrification reactions which have been occurring for more than $10 \mathrm{a}$.

The reaction of aqueous oxidation of pyrite through $\mathrm{Fe}$ reduction is less thermodynamically favourable than $\mathrm{NO}_{3}^{-}$reduction (Table 4), it should take place after all $\mathrm{NO}_{3}^{-}$has been consumed. It indicates that group I well concentrations can be explained by a 3-step evolution: (1) $\mathrm{O}_{2}$ reduction, (2) $\mathrm{NO}_{3}^{-}$reduction, (3) Fe reduction.

\subsection{Relation between biochemical reactions and water fluxes}

The chemical evolution observed in the Ploemeur aquifer is related to the effect of pumping operations on the flow path and redox conditions. Denitrification, did not seem to occur in the aquifer before exploitation started. Furthermore, it seems to be restricted to an area extending North-South of the pumping well along N20 and N150 fault axes. No denitrification occurs, neither to the east nor to the west of the fault. Along the exploitation wells, (i) the fluxes through the weathered part of the aquifer from the eastern part towards the deep fractured part of the aquifer around the pumped well seem to increase, i.e., the influenced radius increases; (ii) the chemical conditions evolve towards more reducing conditions in the weathered part of the aquifer (represented by MF1 and MF2), along the N20 and $\mathrm{N} 150$ faults which seems to be the most reactive area.

The chemical evolution which appears in the Ploemeur aquifer results from the balance between the biochemical reaction, which is kinetically limited, and the physical gradient induced by pumping which controls the velocity of the fluids in the fractures. Both the velocity of the fluid in the fractures and the flow path will be modified by a hydraulic gradient increase. Both can in turn influence the chemical parameters of the reaction by modifying the available reactive surface and the kinetics of the reaction which might be accelerated by increased fluid velocity.

Several processes have been identified, which develop out of balance: (1) initiation of denitrification processes by pumping; (2) autotrophic denitrification in PE showing no $\mathrm{NO}_{3}^{-}$decrease; (3) $\mathrm{Fe}$ reduction although $\mathrm{NO}_{3}^{-}$concentration remains detectable in well F36 and, to a lesser extent, MF1 and MF2. 
(1) In the case of the Ploemeur site, it seems clear that denitrification conditions are met once pumping influences the flow rates and flow paths in the fractures. It implies that more reducing conditions are created, although chemical data suggest that pumping involves a flux of more oxidizing waters from the Eastern part of the aquifer. Since denitrification appears as soon as pumping starts, it can not be related to the introduction of a new water type from another area of the aquifer. The opposite evolution of the $\mathrm{NO}_{3}^{-}$and $\mathrm{SO}_{4}^{2-}$ concentrations which is observed after pumping initiation and after increase of the pumping rate at day 417 is a clear indication of the dependency of the biogeochemical reactions on flow rate. Two models can be proposed:

(i) The denitrification is related to a decrease in the fluid velocity, which in turn is related to the flow increase. The flow increase can induce a change in the velocity distribution i.e. an increase of paths with slow velocities. Decreasing the velocity allows more pronounced chemical reactions consuming $\mathrm{O}_{2}$, which in turn leads to reducing conditions which allow denitrification to proceed. (ii) Pumping mainly increases the fluid velocity in the fractures and the flow paths is not modified. A higher fluid velocity accelerates the chemical kinetics by limiting the diffusion layer and makes the reactive surface more available for reactions, with reaction products being transported rapidly. This allows the $\mathrm{O}_{2}$ to be consumed more rapidly, enabling denitrification to proceed.

(2) There is no clear explanation for the continuing $\mathrm{SO}_{4}^{2-}$ increase for almost 10 a whereas $\mathrm{NO}_{3}^{-}$concentration remains constant. It could results from the contribution of different part of the aquifer, one of them being inefficient with respect to denitrification. The low and constant $\mathrm{NO}_{3}^{-}$concentration is interpreted as a limiting factor to denitrification, the extent of which is almost, but not quite, total and the steady state $\mathrm{SO}_{4}^{2-}$ increase is explained either as: (i) an increase of $\mathrm{NO}_{3}^{-}$supply producing higher $\mathrm{SO}_{4}^{2-}$ concentrations after denitrification or (ii) a steady state increase of the $\mathrm{SO}_{4}^{2-}$ production from pyrite oxidation by $\mathrm{Fe}^{(\mathrm{III})}$. A combination of the two processes cannot however be dismissed. Moreover, assuming a first order kinetic law for denitrifi- cation as reported from several in situ denitrification case studies (Frind et al., 1990; Pauwels et al., 1998; Schürmann et al., 2003), a moderate increase of initial $\mathrm{NO}_{3}^{-}$concentration has a moderate effect on the remaining $\mathrm{NO}_{3}^{-}$concentration, after a time equal to several half lives (difference remains close to the analytical uncertainty). This may be more true, if the denitrification constant has increased during the same period.

(3) After about 10 a of exploitation, the physicochemical conditions seem to evolve towards another step since $\mathrm{S}$ oxidation coupled to $\mathrm{Fe}$ reduction develops in the vicinity of the pumping well, particularly in the weathered part of the aquifer (wells MF1 and MF2). However, the changes in $\mathrm{SO}_{4}^{2-}$ concentrations observed during the last $10 \mathrm{a}$, can also result from the introduction of different waters in the weathered part of the aquifer. The time length $(\sim 10$ a) before reaction seems to be in the order of the residence time scale in the aquifer deduced from the ${ }^{3} \mathrm{H}$ variations. The Fe reduction occurs although the $\mathrm{NO}_{3}^{-}$concentration is above the detection limit. Nitrate and $\mathrm{Fe}$ reduction reactions might combine at the same location owing to micro-site reducing conditions as already suggested on the basis of $\mathrm{N}$ isotopic ratios or in situ microcosm experiments (Moncaster et al., 2000; Bennett et al., 2000). Iron reduction could occur along the $\mathrm{S}$ minerals reactive surface and then the products could diffuse through immobile layers towards the active flow paths. Different redox conditions might also be related to the heterogeneity of the fractured medium, with local reducing conditions developing along slow flow paths, more oxidizing conditions being maintained by the water renewal in the most rapid flow paths.

\section{Conclusions}

An heterogeneous, fractured granitic aquifer (Ploemeur site, Brittany) has been investigated in order to evaluate fluid-flow processes through a fractured bedrock at different scales, both in time and space and the influence of fluid flow distribution on biogeochemical reactions. In the aquifer, pumping at a depth of $100 \mathrm{~m}$ since 1991 creates a fluid flow variation as indicated by the in situ hydraulic 
measurements which indicate that the maximum drawdown depression is located in the pumped well zone and that its influence radius increases with time.

The chemical compositions of the waters sampled all around the pumping well indicate that three main water types are observed in the fractured aquifer. However, their distribution is not related to a vertical stratification between the weathered upper part and the fractured deeper part of the aquifer as observed elsewhere. (1) The first type, representing waters weakly influenced by pumping, are characterized by high $\mathrm{NO}_{3}^{-}$concentrations and low $\mathrm{Na}^{+} / \mathrm{Cl}^{-}$ratios and represent anthropogenic-influenced waters. High ${ }^{3} \mathrm{H}$ content suggests short residence times. These waters are located to the west of the pumping site. (2) The second type is characterised by a reduction of the $\mathrm{NO}_{3}^{-}$and an increase of the $\mathrm{SO}_{4}^{2-}$ concentrations which is attributed to a denitrification process developed in the fractures. (3) The third type shows waters with no large variation in $\mathrm{NO}_{3}^{-}$and $\mathrm{SO}_{4}^{2-}$ concentrations which are in the range 15$40 \mathrm{mg} / \mathrm{L}$. This type of water is thought to represent the "original" composition of the deep aquifer before pumping started.

The second type of waters, showing chemical variations, is observed in the vicinity of the pumping well, along N20 and N150 fault axes. It also corresponds to the evolution observed in the pumping well. Low ${ }^{3} \mathrm{H}$ content indicates longer residence times, in the order of several tens of years. The chemical composition of the pumping well indicates that the quality of the groundwater has changed since exploitation began. The $\mathrm{SO}_{4}^{2-}$ and $\mathrm{NO}_{3}^{-}$variations through time are clearly negatively-correlated at the onset of the pumping and 417 days after the beginning of pumping operations when the pumping rate is doubled. Afterwards, the $\mathrm{SO}_{4}^{2-}$ increases although $\mathrm{NO}_{3}^{-}$concentrations became constant. During the last years, the pumped waters and the waters in the vicinity of the pumping well show a clear $\mathrm{SO}_{4}^{2-}$ increase (with values up to $500 \mathrm{mg} / \mathrm{L}$ ).

This study demonstrates the influence of the physical parameters of the transfer, i.e., the more important flows induced by the pumping, on the chemistry of the waters. Initiation of the pumping in the aquifer has led to the onset of the denitrification reactions. This is attributed either: (i) to the acceleration of the $\mathrm{O}_{2}$ consuming reactions by the increase of the fluid velocity in the fractures which accelerates the chemical kinetics or, (ii) to the $\mathrm{O}_{2}$ consuming reaction developed by the decrease of the fluid velocity due in turn to the increase of the flow paths heterogeneity. Experimental modelling should be attempted in order to understand more precisely the controls of physical flow distribution on the chemical reactions.

\section{Acknowledgements}

The authors are very grateful to the Mayor and staff of Ploemeur City for their important contributions. Part of the project was funded by European project SALTRANS. The "Conseil Régional de Bretagne" also provided funding. Funding for Virginie Ayraud was provided by BRGM. We thank Jo Cotten, Jean-Yves Cabon, Odile Hénin and Martine Bouhnik-Le Coz who carried out the chemical analyses. Special thanks are also due to Pr. Robin W. Renaut (University of Saskatchewan, Canada) for the revision of our English text, and to R. Jacobsen, M. Lindsay and M. Edmunds for their constructive comments.

\section{References}

Appelo, C.A.J., Postma, D., 1993. Geochemistry, Groundwater and Pollution. A.A. Balkema, Rotterdam.

Aquilina, L., de Dreuzy, J.R., Bour, O., Davy, P., 2004. Porosity and fluid velocities in the upper continental crust ( 2 to $4 \mathrm{~km}$ ) inferred from injection tests at the Soultz-sous-Forêts geothermal site. Geochim. Cosmochim. Acta 68, 2405-2415.

Barker, J.A., 1988. A generalized radial flow model for hydraulic tests in fractured rocks. Water Resour. Res. 24, 1796-1804.

Bennett, P.C., Hiebert, F.K., Rogers, J.A., 2000. Microbial control of mineral-groundwater equilibria: Macroscale to microscale. Hydrogeol. J. 8, 47-62.

Berner, R.A., 1981. Authigenic mineral formation resulting from organic matter decomposition in modern sediments. Fortsch. Mineral. 59, 117-135.

Böhlke, J.K., Denver, J.M., 1995. Combined use of groundwater dating, chemical, and isotopic analyses to resolve the history and fate of nitrate contamination in two agricultural watersheds, Atlantic coastal plain, Maryland. Water Resour. Res. 31, 2319-2339.

Böhlke, J.K., Wanty, R., Tuttle, M., Delin, G., Landon, M., 2002. Denitrification beneath the recharge area and discharge area of a transient agricultural groundwater nitrate plume in Minnesota. Water Resour. Res. 30, 1-26.

Böttcher, J., Strebel, O., Voerkelius, S., Schmidt, H.L., 1990. Using isotope fractionation of nitrate-nitrogen and nitrateoxygen for evaluation of microbial denitrification in a sandy aquifer. J. Hydrol. 114, 413-424.

Bouhnik-Le Coz, M., Petitjean, P., Serrat, E., Gruau, G., 2001. Validation d'un protocole permettant le dosage simultané des cations majeurs et traces dans les eaux douces naturelles par ICP-MS, Rennes: Géosciences Rennes. Les cahiers techniques de Géosciences (1). 
Bour, O., Davy, P., 1997. Connectivity of random fault networks following a power law fault length distribution. Water Resour. Res. 33, 1567-1583.

Brenner, F.J., Mondok, J.J., 1995. Nonpoint source pollution potential in an agricultural watershed in northwestern Pennsylvania. Water Resour. Bull. 31, 1101-1112.

Champ, D.R., Gulens, J., Jacquson, R.E., 1979. Oxidationreduction sequences in groundwater flow systems. Can. J. Earth Sci. 16, 12-23.

Chapelle, F.H., McMahon, P.B., Dubrovsky, N.M., Fujii, R.F., Oaksford, E.T., Vroblesky, D.A.., 1995. Deducing the distribution of terminal electron-accepting process in hydrologically diverse groundwater systems. Water Resour. Res. 31, 359-371.

Engesgaard, P., Kipp, K.L., 1992. A geochemical transport model for redox-controlled movement of mineral fronts in groundwater flow systems: A case of nitrate removal by oxydation of pyrite. Water Resour. Res. 28, 2829-2843.

Frind, E.O., Duynisveld, W.H.M., Strebel, O., Böttcher, J., 1990. Modeling of multicomponent transport with microbial transformation in groundwater: The Fuhrberg case. Water Resour. Res. 26, 1707-1719.

Grambell, R.P., Gilliam, J.W., Weed, S.B., 1975. Nitrogen losses from soils of the North Carolina Coastal Plain. J. Environ. Qual. 4, 317-322.

Hering, J.G., Stumm, W., 1990. Oxidation and reductive dissolution of minerals. In: Hochella, M.F., Jr.Jr., White, A.F. (Eds.), Reviews in Mineralogy, vol. 23, Mineral-Water Interface Geochemistry. Mineral Society of America, Washington, USA, pp. 427-465.

Hill, A.R., 1978. Factors affecting the export of nitrate-nitrogen from drainage basins in southern Ontario. Water Res. 12, $1045-1057$.

Howard, K.W.F., 1985. Denitrification in a major limestone aquifer. J. Hydrol. 76, 265-280.

IAEA/WMO (2004). Global Network of Isotopes in Precipitation. The GNIP Database. Accessible at: http:// isohis.iaea.org.

Jordan, T.E., Weller, D.E., 1996. Humans contributions to terrestrial nitrogen flux. BioSciences 46, 655-664.

Jordan, T.E., Corell, D.L., Weller, D.E., 1997. Relating nutrient discharges from watersheds to land use and streamflow variability. Water Resour. Res. 33, 2579-2590.

Koenig, A., Liu, L.H., 1996. Autotrophic denitrification of landfill leachate using elemental sulphur. Water. Sci. Technol. 34, 469-476.

Kölle, W., Strebel, O., Böttcher, J., 1985. Formation of sulfate by microbial denitrification in a reducing aquifer. Water Supply 3, 35-40

Korom, S.F., 1992. Natural denitrification in the saturated zonea review. Water Resour. Res. 28, 1657-1668.

Le Borgne, T., Bour, O., de Dreuzy, J.R., Davy, P., Touchard, F., 2004. Equivalent mean flow models for fractured aquifers: Insights from a pumping tests scaling interpretation. Water Resour. Res. 40, W03512. doi:10.1029/2003WR002436.

Mariotti, A., 1986. La dénitrification dans les eaux souterraines, principes et méthodes de son identification: une revue. J. Hydrol. 88, 1-23.

Mariotti, A., Landreau, A., Simon, B., $1988 .{ }^{15} \mathrm{~N}$ isotope biogeochemistry and natural denitrification process in groundwater: Application to the chalk aquifer of northern France. Geochim. Cosmochim. Acta 52, 1869-1878.
Martin, C., 2003. Mécanismes hydrologiques et hydrochimiques impliqués dans les variations saisonnières des teneurs en nitrates dans les bassins versants agricoles: approche expérimentale et modélisation. PhD thesis, Univ. Rennes 1 , Memoires du Caren 4, Rennes.

Martin, C., Aquilina, L., Gascuel-Odoux, C., Molénat, J., Faucheux, M., Ruiz, L., 2004. Seasonal and interannual variations of nitrate and chloride in stream waters related to spatial and temporal patterns of groundwater concentration in agricultural catchments. Hydrol. Process. 18, 1237-1254.

Mason, J.W., Wegner, G.D., Quinn, G.I., Lange, E.L., 1990. Nutrient loss via groundwater discharge from small watersheds in southwestern and south central Wisconsin. J. Soil Water Conserv. 45, 327-331.

Moncaster, S.J., Bottrell, S.H., Tellam, J.H., Lloyd, J.W., Konhauser, K.O., 2000. Migration and attenuation of agrochemical pollutants: insights from isotopic analysis of groundwater sulphate. J. Contamin. Hydrol. 43, 147-163.

Neretnieks, I., 1985. Transport in fractured rocks, In: Proceedings in Hydrogeology of Rock of Low Permeability, Mem. Internat. Assoc. Hydrogeol., vol. 17, pp. 301-318.

Osborne, L.L., Wiley, M.J., 1988. Empirical relationships between land use/cover and stream water quality in an agricultural watershed. J. Environ. Manag. 26, 9-27.

Parkhurst, D.L., Appelo, C.A.J., 1999. User's guide to PHREEQC (Version 2) - A computer program for speciation, batchreaction, one-dimensional transport and inverse geochemical calculations. US Geol. Surv. Water-Resour. Investig. Rep. 99-4259. (Available at: http://water.usgs.gov/software/ geochemical.html).

Pauwels, H., Kloppmann, W., Foucher, J.C., Martelat, A., Fritsche, V., 1998. Field tracer test for denitrification in a pyrite-bearing schist aquifer. Appl. Geochem. 13, 767-778.

Pauwels, H., Foucher, J.C., Kloppmann, W., 2000. Denitrification and mixing in a schist aquifer: influence on water chemistry and isotopes. Chem. Geol. 168, 307-324.

Pauwels, H., Lachassagne, P., Bordenave, P., Foucher, J.C., Martelat, A., 2001. Temporal variability of nitrate concentration in a schist aquifer and transfer to surface waters. Appl. Geochem. 16, 583-596.

Postma, D., Boesen, C., Kristiansen, H., Larsen, F., 1991. Nitrate reduction in an unconfined sandy aquifer: water chemistry, reduction processes, and geochemical modeling. Water Resour. Res. 27, 2027-2045.

Puckett, L.J., Cowdery, T.K., 2002. Transport and fate of nitrate in a glacial outwash aquifer in relation to ground water age, land use practices, and redox processes. J. Environ. Qual. 31, 782-796.

Puckett, L.J., Cowdery, T.K., Lorenz, D.L., Stoner, J.D., 1999. Estimation of nitrate contamination of an agro-ecosystem aquifer using a nitrogen mass-balance budget. J. Environ. Qual. 28, 2015-2020.

Rödelsperger, M., 1989. Natural denitrification processes in the aquifer. In: Kobus, H., Kinzelbach, W. (Eds.), Proceedings of Symposium on Contaminant Transport in Groundwater. A.A. Balkema, Rotterdam, Netherlands, pp. 159-163.

Roussel, G., Gallat, G., 1996. Bilan Corpen: Etude agronomique et d'environnement: Site de Ploemeur (Morbihan), Rapport Géoarmor.

Schürmann, A., Schroth, M.H., Saurer, M., Bernasconi, S.M., Zeyer, J., 2003. Nitrate-consuming processes in a petroleumcontaminated aquifer quantified using push-pull tests com- 
bined with ${ }^{15} \mathrm{~N}$ isotope and acetylene-inhibition methods. J. Contam. Hydrol. 66, 59-77.

Smith, R.L., Howes, B.L., Duff, J.H., 1991. Denitrification in nitrate-contaminated ground water: occurrence in steep vertical geochemical gradients. Geochim. Cosmochim. Acta 55, 1815-1825.

Spalding, R.F., Exner, M.E., 1993. Occurence of itrate in groundwater: A review. J. Environ. Qual. 22, 392-402.

Stumm, W., Morgan, J.J., 1981. Aquatic Chemistry. John Wiley, New York.
Tesoriero, A.J., Liebscher, H., Cox, S.E., 2000. Mechanism and rate of denitrification in an agricultural watershed: electron and mass balance along groundwater flow paths. Water Resour. Res. 36, 1545-1559.

Touchard, F., 1999. Etude hydrogéologique d'un aquifère en socle fracturé: site de Ploemeur (Morbihan), PhD Thesis, Univ. Rennes 1.

Webb, J.A., Sasowsky, I.D., 1994. The interaction of acid mine drainage with a carbonate terrane: evidence from the Obey River, north-central Tennessee. J. Hydrol. 161, 327-346. 